\title{
A CONSTITUTION FOR JUDICIAL LAWMAKING
}

\author{
Adam N. Steinman ${ }^{*}$
}

\begin{abstract}
When courts decide cases, their decisions make law because they become precedent that binds future courts under the doctrine of stare decisis. This article argues that judicial lawmaking, like legislative lawmaking, is subject to constitutional principles that govern the extent to which a particular attempt at judicial lawmaking is valid. Because even poorly reasoned judicial decisions can still be effective lawmaking acts, it is important to distinguish between constitutional and non-constitutional principles and arguments. While a non-constitutional principle can be a basis for examining the wisdom or merits of a particular lawmaking act, only constitutional principles can assess whether the lawmaking act is valid.

Although the constitutional principles governing judicial lawmaking are not expressly set forth in a written constitution, this article articulates a methodology for identifying the fundamental constitutional limits on judicial lawmaking. It then explains how this constitutionalist approach fits with various strands of legal theory, including formalism, realism, positivism, legal process, and critical legal studies. Finally, this article begins to examine the implicit constitution that governs judicial lawmaking in the federal system, explicating some of the key issues that define its contours and that can shape future development and critique.
\end{abstract}

* Assistant Professor of Law (Designate), University of Cincinnati College of Law. B.A., Yale College; J.D., Yale Law School. 
Table of Contents

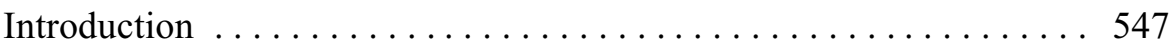

I. Methodology: What is the Constitution for Judicial Lawmaking? 550

A. What Kind of Lawmaking? . . . . . . . . . . . . . . 552

B. What Kind of Constitution? ............... 554

II. Why Adopt a Constitutional View of Judicial Lawmaking? . . . . 555

A. Where Formalism and Realism Collide .......... 556

B. Other Schools of Legal Theory . . . . . . . . . . . . . . . . 562

C. The Normativity of the Constitutionalist Theory . . . . . . . 564

D. A Constitution Without Text? . . . . . . . . . . . . . . 568

E. Practical Implications . . . . . . . . . . . . . . . . . . . . 569

III. The Constitution of Judicial Lawmaking in the Federal Judiciary 570

A. Enumerated Powers . . . . . . . . . . . . . . . 570

B. The Judiciary's Power to Change Its Own Law . . . . . . . . 575

C. The Judiciary's Power to Deprive Its Own Decisions of

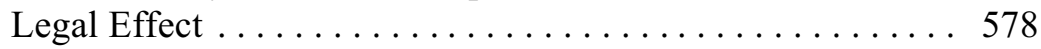

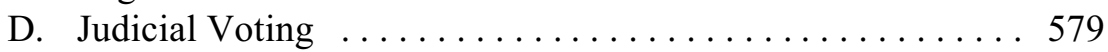

IV. Making Sense of the Constitution for Judicial Lawmaking . . . . 582

A. Why Should Courts Make Law at All? ............ 583

B. Why Place Limits on Judicial Lawmaking? . . . . . . . . 584

C. Revisiting the Articles of Judicial Lawmaking's

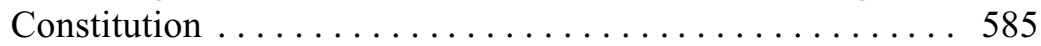

1. Dicta and Holdings: Beyond the OutcomeRationale Debate ....................... 586

2. Should Stare Decisis Be Part of Our Constitution for Judicial Lawmaking? . . . . . . . . . . . . . . . . 590

3. Unpublished Decisions and the Power Not to Make Law . . . . ........................ 591

4. Judicial Voting and One Alternative to Marks-ism . . . . 593 Conclusion .......................... 596 
"I recognize without hesitation that judges do and must legislate."

$$
\text { -Justice Oliver Wendell Holmes }{ }^{1}
$$

"I am not so naive (nor do I think our forebears were) as to be unaware that judges in a real sense 'make' law."

-Justice Antonin Scalia ${ }^{2}$

"[I]t is a constitution we are expounding."

-Chief Justice John Marshall ${ }^{3}$

\section{INTRODUCTION}

Judges make law. ${ }^{4}$ This fact — and its consequences — has been a key area of study and debate in the legal academy. Concepts such as the countermajoritarian difficulty ${ }^{5}$ and judicial activism, ${ }^{6}$ as well as numerous jurisprudential theories, are all concerned with the propriety of such lawmaking and how judges should (or should not) perform their lawmaking functions. Such scholarship tends to draw a distinction between judicial

1. S. Pac. Co. v. Jensen, 244 U.S. 205, 221 (1917) (Holmes, J., dissenting).

2. James B. Beam Distilling Co. v. Georgia, 501 U.S. 529, 549 (1991) (Scalia, J., concurring).

3. McCulloch v. Maryland, 17 U.S. 316, 407 (1819).

4. Alexander M. Bickel, The Least Danger ous Branch: The Supreme Court at the Bar of Politics 16-23 (1962); John Hart Ely, Democracy and Distrust: A Theory of Judicial Review 1-9 (1980); Aharon Barak, Foreward: A Judge on Judging: The Role of a Supreme Court in a Democracy, 116 Harv. L. Rev. 16, 62 (2002) ("Judges make law, and the public should know that they do.”); Christopher J. Peters, Adjudication as Representation, 97 Colum. L. Rev. 312, 315 (1997) ("[C]ourts do make laws (or, if you prefer, rules) that govern us[.]"); Edward L. Rubin \& Malcolm M. Feeley, Judicial Policy Making and Litigation Against the Government, 5 U. PA. J. Const. L. 617, 639 (2003) ("As virtually every political scientist who studies courts asserts, and as discussed at length in our book, courts make public policy.”); Frederick Schauer, Opinions as Rules, 53 U. CHI. L. Rev. 682, 684 (1986) (reviewing Bernard Schwartz, The Unpublished Opinions of the Warren Court (1985)) (noting that "the words of a[] [judicial] opinion take on a canonical role not unlike that played by the words in a statute").

5. See Bickel, supra note 4, at 16-23; Ely, supra note 4, at 1-9; Jack M. Balkin \& Sanford Levinson, Understanding the Constitutional Revolution, 87 VA. L. REv. 1045 (2001); Barry Friedman, The Birth of an Academic Obsession: The History of the Countermajoritarian Difficulty, Part Five, 112 YALE L.J. 153 (2002); Barry Friedman, Dialogue and Judicial Review, 91 Мich. L. ReV. 577 (1993).

6. Balkin \& Levinson, supra note 5, at 1081; Randy E. Barnett, Is the Rehnquist Court an "Activist" Court?: The Commerce Clause Cases, 73 U. Colo. L. Rev. 1275, 1275-77 (2002); Peters, supra note 4 , at $317-18$. 
lawmaking and legislative lawmaking. While democratically elected legislatures are free to base lawmaking decisions on raw political, ideological, or personal considerations, judicial lawmaking is supposed to be a more refined art - one that accounts for past legal precedent and is based on a coherent analysis of what the law "is," rather than what it "should be.""

As a practical matter, however, judges make law even when their decisions are inelegant, incoherent, or inconsiderate of the relevant legal sources, arguments, and implications. Such decisions may deserve criticism and may even be deemed "wrongly decided." Nonetheless, it is still the judges - not the critics - who make law, and a poorly reasoned decision can still be an effective act of judicial lawmaking. Just as a legislature makes law even when the resulting statute resembles a pig's ear $^{8}$ and the legislative process a sausage factory, ${ }^{9}$ so can the judiciary make law even when its decisions fail to meet the standards of judicial lawmaking that many expect.

This article embraces the comparison between judicial and legislative lawmaking, and views judicial lawmaking through a legislative lens. While many perceive legislative lawmaking as being subject to no constraints other than the next election, the truth is that legislative lawmaking is not unbounded. Legislative lawmaking is typically constrained by a constitution, one which sets procedural and substantive limits on the lawmaking function. Constitutionalism, as Frank Michelman has stated, is the "'law of lawmaking'

7. See Robert H. Bork, The Tempting of America: The Political Seduction of the Law 2 (1990) ("A judge who announces a decision must be able to demonstrate that he began from recognized legal principles and reasoned in an intellectually coherent and politically neutral way to his result.").

8. See Lindh v. Murphy, 521 U.S. 320, 336 (1997) ("All we can say is that in a world of silk purses and pigs' ears, the Act is not a silk purse of the art of statutory drafting.").

9. The comparable ugliness of legislating and sausage-making is frequently noted in legal scholarship. David Luban, No Rules?: Considering Values Asking the Right Questions, 72 TemP. L. Rev. 839,847 (1999) ("'A] first peek in to the legislative sausage factory is indescribably revolting."); Richard J. Pierce, Jr., Reconciling Chevron and Stare Decisis, 85 GEO. L.J. 2225, 2235 (1997) ("When that statute emerges from the sausage factory that is the legislative process, it invariably includes scores of gaps, ambiguities, and internally inconsistent provisions."); Peter L. Strauss, The Courts and the Congress: Should Judges Disdain Political History?, 98 Colum. L. Rev. 242, 265 n.92 (1998) ("[F]or legislation as for sausages, one should enjoy the result, but not watch the making.") (citing Cmty. Nutrition Inst. v. Block, 749 F.2d 50, 51 (D.C. Cir. 1984)). The analogy is often attributed to Otto von Bismark. See Edward L. Rubin, The Concept of Law and the New Public Law Scholarship, 89 Mich. L. Rev. 792, 806 (1991) (noting "Bismark's observation that anyone who loves law or sausage should not watch either being made"); Peter L. Strauss, The Common Law and Statutes, 70 U. Colo. L. Rev. 225, 240 \& nn.38-41 (1999) ("However one likes statutes or sausages, one should not watch them being made."). But some have cited Sir Winston Churchill. See Bernard Schwartz, Curiouser and Curiouser: The Supreme Court's Separation of Powers Wonderland, 65 Notre Dame L. Rev. 587, 600 (1990) (“[A] legislative body is, to paraphrase Sir Winston Churchill, hardly worthy of the title of Congress if it merely grinds out laws as a sau sage-maker grinds out sausages.”). 
... that controls which further laws can be made and by what procedures."10 In our system, the process of judicial review provides for meaningful enforcement of these constitutional norms, because unconstitutional laws may be invalidated. The character of legislative lawmaking, therefore, depends in large part on the constitutional requirements with which such lawmaking must comply. This is, no doubt, why the scope and meaning of these constitutional limits garners such a large share of attention.

The purpose of this article is to examine judicial lawmaking from this same constitutional perspective. By "constitutional," I do not mean "deriving from the United States Constitution." Rather, I am referring to principles that set forth the "law" of judicial lawmaking. My criteria have nothing to do with whether a particular principle of judicial lawmaking literally stems from the United States Constitution. Instead, the key inquiry is whether the principle sets an enforceable restriction on judicial lawmaking, such that actors other than the initial lawmaking tribunal may treat an attempt at judicial lawmaking as invalid if it runs afoul of that principle. Such restrictions are "constitutional" in the sense that they set substantive limits on judicial lawmaking and the procedures with which judicial lawmaking must comply.

Thus, this article sets forth a constitutionalist theory of judicial lawmaking and explains what our constitution for federal judicial lawmaking looks like. Part I describes in greater detail the concept of a constitution for judicial lawmaking and sets forth my methodology for identifying truly "constitutional" rules. Part II explains how my constitutionalist approach incorporates, reconciles, and interfaces with other theories of judicial lawmaking. It also argues that a constitutional view of judicial lawmaking is valuable from both a practical and theoretical perspective. Part III sets forth the current "articles" of judicial lawmaking's constitution and explains some of the key issues that define the contours of this constitution as it presently exists. Specifically, I examine the dictum-holding distinction, the judiciary's power to change its law, the judiciary's power to deprive its decisions of lawmaking effect, and judicial voting. Part IV looks holistically at the constitution for judicial lawmaking and identifies the core principles implicated by the constitutional limits on judicial lawmaking. I then explain

10. Frank I. Michelman, Brennan and Democracy: The 1996-97 Brennan Center Symposium Lecture, 86 CAL. L. REv. 399, 400 (1998) [hereinafter Michelman, Brennan]; accord Frank I. Michelman, Living with Judicial Supremacy, 38 WAKe Forest L. ReV. 579, 588 (2003) [hereinafter Michelman, Judicial Supremacy] (stating that the term "constitution" includes "a table of who-how identified or selected, acting by what procedural forms — gets to lay down the law and apply it decisively" and "some set of legal limits and constraints on what may or must be laid down as law by legal authorities"). 
how these principles are affected by possible solutions to some of the more challenging issues surrounding the practical application of judicial lawmaking's constitution.

\section{Methodology: What is the Constitution for Judicial LAWMAKING?}

The purpose of this article is to identify and elucidate the constitution that governs judicial lawmaking. This constitutional perspective is achieved by analogizing judicial lawmaking to legislative lawmaking. ${ }^{11}$ For legislative bodies, a constitution defines the substantive and procedural limits on lawmaking. A constitution may set such limits with varying degrees of specificity. But when an act of legislative lawmaking violates these limits, judges may treat that law as invalid.

Take the United States Constitution's limits on legislative lawmaking, for example. Procedurally, a bill becomes law if it is passed by majorities in both the Senate and the House and is signed by the President. ${ }^{12}$ If the President vetoes a bill, then a bill may become law if two-thirds of the House and Senate override the veto. ${ }^{13}$ Substantively, Congress may only make laws in the areas

11. Commentators have made this analogy frequently. See Kent Greenawalt, Discretion and Judicial Decision: The Elusive Quest for the Fetters that Bind Judges, 75 CoLum. L. Rev. 359, 359 (1975) (noting Cardozo's "characteristically eloquent formulation of the thesis that judges "legislate" (citing Benjamin Cardozo, The Nature of the Judicial Process (1921)); Schauer, supra note 4, at 684 (noting that "the words of a[] [judicial] opinion take on a canonical role not unlike that played by the words in a statute"); Peters, supra note 4, at $361 \&$ n.179 ("Court decisions thus can serve as rules in much the same way that statutes do, encouraging and discouraging certain kinds of conduct with the promise that such conduct will bear particular legal consequences."); Frederick Schauer, Refining the Lawmaking Function of the Supreme Court, 17 U. Mich. J.L. Reform 1, 2 (1983) ("To the extent that we expect others to follow the Supreme Court's lead, and to obey its directives, then those others occupy a position with respect to the Court that is not dissimilar to that occupied by the citizen with respect to a legislature."); Michael B.W. Sinclair, Legal Education: What is the " $R$ " in "Irac"?, 46 N.Y.L. ScH. L. REv. 457, 457-58 (2002) ("Judicial decisions (cases) stand for rules; there are rules in opinions, of much the same kind as we find in statute books. One eminent jurisprude, Ronald Dworkin, called it the 'enactment theory.' It is this sense that Judge Easterbrook used when he wrote, 'Judges both resolve disputes and create rules."') (quoting Ronald Dworkin, Taking Rights Seriously 111 (1977)); Frank Easterbrook, The Supreme Court 1983 Term, Forward: The Courts and the Economic System, 98 Harv. L. Rev. 4, 5 (1984). But see Henry Paul Monaghan, Stare Decisis and Constitutional Adjudication, 88 Colum. L. Rev. 723, 756-57 (1988) ("Professor Goodhart insisted that for the English courts precedents constituted judge-made statutes.... The view that a judicial precedent is the equivalent of a legislative act has never existed in American law, and no one has proposed that it should.").

12. U.S. Const. art. I, § 7, cl. 2.

13. Id. 
enumerated in the Constitution, ${ }^{14}$ e.g., to regulate interstate commerce, ${ }^{15}$ to establish uniform rules for immigration and bankruptcy, ${ }^{16}$ or to enforce the provisions of the Fourteenth Amendment. ${ }^{17}$ Even when Congress legislates in one of these enumerated areas, the Bill of Rights and other constitutional provisions place additional substantive limits on federal legislation. Legislation may not, for example, abridge freedom of speech or freedom of press, ${ }^{18}$ impose cruel or unusual punishment, ${ }^{19}$ or deny any person the equal protection of law. ${ }^{20}$

These constitutional norms are enforceable, because judges who otherwise would be required to apply such laws may treat unconstitutional laws as invalid. If Congress attempts to make law without following the constitutionally required procedures, the law is unenforceable. ${ }^{21}$ If a statute violates a substantive limit on lawmaking, either by exceeding Congress's enumerated powers or violating some other substantive limit on lawmaking (such as the Bill of Rights), then that law may be treated as invalid by the judiciary. ${ }^{22}$

Therefore, legislatures make law, and their lawmaking authority is limited by constitutions. Judges make law, and their lawmaking is limited by-what? Generally, the substantive and procedural limits on judicial lawmaking are not expressly articulated in any written document. I argue, however, that judicial lawmaking is also limited by constitutional principles, if one defines the term "constitutional" functionally (based on the nature of the rule) rather than literally (based on the source of the rule). Before explaining this distinction, it is helpful to clarify what kind of judicial lawmaking is my focus.

14. See generally id. $\S 8$.

15. Id., cl. 3.

16. Id., cl. 4.

17. U.S. Const. amend. XIV, $\S 5$.

18. Id. amend. I.

19. Id. amend. VIII.

20. Id. amend. XIV, $\S 1$.

21. E.g., INS v. Chadha, 462 U.S. 919 (1983) (striking down statute allowing for legislative veto of regulations).

22. E.g., Dickerson v. United States, 530 U.S. 428 (2000) (holding that statute violated constitutional rights under Miranda v. Arizona, 384 U.S. 436 (1966)); United States v. Lopez, 514 U.S. 549 (1995) (holding that statute exceeded Congress's power under the Commerce Clause). 


\section{A. What Kind of Lawmaking?}

Judges make law in a number of different ways. In the most conventional sense, a court's issuance of a final judgment is itself a legal decree. It is a legally binding document, which the prevailing party may seek to have enforced by a variety of measures. A structural injunction is one example of the kind of judicial lawmaking that occurs when a judge issues a judgment that binds the parties to that case. ${ }^{23}$ Judges may also make law by promulgating rules, as would an administrative agency. The United States Supreme Court, for example, promulgates the Federal Rules of Civil Procedure, Criminal Procedure, and Appellate Procedure, as well as the rules governing practice in the Supreme Court. ${ }^{24}$ Other federal courts issue local rules that govern practice and procedure before them, consistent with the rules and statutes governing the federal courts generally. ${ }^{25}$

These judicial functions are, to be sure, important lawmaking roles for the judiciary, but they are not the focus of this article. Rather, I am concerned with the lawmaking that occurs when judges issue decisions that create binding precedent for future cases ${ }^{26}$ Judicial decisions make prospective law because of the doctrine of stare decisis. ${ }^{27}$ Thus, this article focuses on the judicial opinion as the central lawmaking act for judges, just as the statute is the central lawmaking act for legislatures.

The lawmaking function created by stare decisis is inherent in the common law judicial system. As one commentator has explained (paraphrasing Justice Scalia):

Presented with a fact pattern, a judge simply decided what the result should be and cited specific features of the circumstances to support the decision. Such a decision became law by virtue of the doctrine of stare decisis. Decisions thereby acquired the permanence required of laws. Otherwise, courts would "just be resolving the particular dispute before them." ${ }^{28}$

23. Rubin \& Feeley, supra note 4, at 618-19 (citing Owen M. Fiss, Foreward: The Forms of Justice, 93 Harv. L. Rev. 1 (1979)).

24. See 28 U.S.C. $\S \S 2071$ (a), 2072(a) (2000).

25. See id. § 2071(a).

26. See Schauer, supra note 11, at 5-6 (noting that courts perform two kinds of lawmaking: adjudicating the dispute and "promulgat[ing] norms for the guidance of lower courts, legislatures, executive departments, public employees, and the public").

27. This well-known principle is Latin for "to stand by things decided." BlaCK's LAw Dictionary 1414 (7th ed. 1999).

28. David Sosa, The Unintentional Fallacy, 86 CAL L. Rev. 919, 921 (1998) (book review)(citing 
Indeed, such lawmaking flows directly from the very process of judicial review. As Frank Michelman explains:

[J]udicial review easily means all of the following: (1) that the Supreme Court rules on the constitutional legality of statutes and other political acts, when such questions come before the Court in the exercise of what it finds - we assume not outrageously - to be its jurisdiction; (2) that the Court's specific orders based on such rulings are considered obligatory by every other court and public official; (3) that the rulings themselves, informed by the reasoning given in support of them, stand as precedents for lower courts adjudicating future similar or related cases, and for the Supreme Court, too, subject to possible overruling by it; and (4) that all other public officials consider themselves under obligation to conduct their affairs with a commonsensical regard to all of the foregoing (so they do not, for example, go around arresting people on charges of breaking laws that already have been held unconstitutional by a final judgment of the Supreme Court). ${ }^{29}$

By a similar process, a court's interpretation of statutes can produce a lawmaking function that will bind future courts as well, ${ }^{30}$ although Congress is obviously free to amend statutes to correct a judicial interpretation with which it disagrees.

One important distinction is worth keeping in mind when analyzing judicial lawmaking activity. Certain aspects of a judicial decision may be relied on by subsequent courts, even though that part of the decision is not binding precedent that must be followed under stare decisis. This alone does not make those decisions effective acts of lawmaking. They may constitute persuasive authority, just as a law review article or a decision from a foreign tribunal may convince a court to decide a case in a particular way. A court may follow a prior opinion "because it is logical" or "because it is just," but that does not mean that the part of the opinion being followed was a binding act of judicial lawmaking. ${ }^{31}$ A judicial decision is truly binding when it "must be followed because it is a previous decision and for no other reason." ${ }^{32}$ The focus of this article, therefore, is judicial lawmaking that is formally binding - via stare decisis — on subsequent tribunals.

Antonin Scalia, A Matter of Interpretation 7 (1997)).

29. Michelman, Judicial Supremacy, supra note 10, at 594.

30. Rubin \& Feeley, supra note 4, at 639 ("[C]ourts sometimes state rules even when they are merely interpreting a statute.").

31. Monaghan, supra note 11, at $757 \mathrm{n} .187$ ("I agree with Radin's assertion that stare decisis is not involved if the court 'follows a previous decision ... because it is the right decision, because it is logical, because it is just."') (quoting Max Radin, Case Law and Stare Decisis: Concerning Präjudizienrecht in Amerika, 33 Colum. L. Rev. 199, 200 (1933)).

32. Radin, supra note 31 , at 200. 


\section{B. What Kind of Constitution?}

Written constitutions often do not enumerate substantive and procedural limits for judicial lawmaking with the same detail that they do for legislative lawmaking. Nonetheless, judicial lawmaking is subject to rules that have a constitutional quality. Constitutionalism, after all, entails what Frank Michelman has generally called "the "law of lawmaking." 33 A "constitution" comprises "a table of who-how identified or selected, acting by what procedural forms - gets to lay down the law and apply it decisively" and a "set of legal limits and constraints on what may or must be laid down as law by legal authorities[.]" ${ }^{34}$

Consistent with this approach, my understanding of judicial lawmaking's constitution is functional, rather than literal. Rule X is a constitutional rule if an act of judicial lawmaking that violates Rule $\mathrm{X}$ may be regarded as ineffective. These constitutional rules define the outer limits of judicial lawmaking authority. If a judicial decision complies with these rules, then it is an effective act of judicial lawmaking. Otherwise, it is not. Thus, the constitutional rules for federal judicial lawmaking will not necessarily derive from the United States Constitution. Rather, the constitution for judicial lawmaking is mostly a collection of judicially-created doctrines, which combine to set enforceable limits on the judicial lawmaking function. To borrow a phrase from Kent Greenawalt, articulating the constitution of judicial lawmaking is one aspect of "The Elusive Quest for the Fetters that Bind Judges." ${ }^{35}$

For these fetters truly to bind, however, it is important that the constitutional requirements be enforceable. With legislative lawmaking, most constitutional norms are enforced by the process of judicial review. While judicial enforceability of constitutional norms may not be absolutely necessary for the rule of law to prevail, judicial review and enforcement is, as Michelman has noted, "a rock-solid component of American government and political self-understanding." 36 This enforceability element is particularly

33. Michelman, Brennan, supra note 10, at 400.

34. Michelman, Judicial Supremacy, supra note 10, at 588. See also Michael J. Klarman, What's So Great About Constitutionalism, 93 Nw. U. L. REv. 145, 183 (1998) (“[J]udges still require a set of background rules that establish the criteria for valid legislation — for example, to be valid, a law must be passed by which institution using what voting rule? This is constitutionalism in the British sense.").

35. Greenawalt, supra note 11, at 359.

36. Michelman, Judicial Supremacy, supra note 10, at 593. See also Klarman, supra note 34, at 146 ("[W] hen I discuss constitutionalism I am principally concerned with its judicially-enforceable variety. I do not, of course, mean to deny the possibility of constitutionalism without judicial review."). 
significant in the context of judicial lawmaking because, after all, the duty of determining the precedential impact of a particular decision lies not with the precedent-setting court but with the precedent-applying court. ${ }^{37}$

These principles are what will guide my effort to articulate the constitution for judicial lawmaking. In doing so, it is worth recalling Chief Justice Marshall's famous statement that "[i]t is a constitution we are expounding." " To "expound" is defined as: "[T] give a detailed statement of; set forth. To explain in detail, elucidate." ${ }^{" 39}$ Chief Justice Marshall was referring to the process of articulating the meaning of the United States Constitution through the process of judicial review. He was working from a fixed document and attempting to explain what that document required as applied to particular cases. The identification and articulation of the constitution that governs judicial lawmaking is also an expounding process. It is, essentially, an attempt to expound a constitution from scratch - to reverse engineer the constitution of judicial lawmaking from the disparate principles and doctrines that currently exist.

\section{Why Adopt a Constitutional View of Judicial Lawmaking?}

Approaching judicial lawmaking from this constitutional perspective is worthwhile because it will sharpen an important distinction in jurisprudential analysis. While a non-constitutional principle can be a basis for examining the wisdom or merits of a particular lawmaking act, only constitutional principles can determine whether that lawmaking act is valid. This distinction will allow judges, scholars, and practitioners to more explicitly frame arguments about the judicial lawmaking function in a way that builds on existing legal theories. It will also allow a deeper understanding of judicial lawmaking systems, because the constitutional limits are what stake the fundamental boundaries of valid lawmaking activity.

This constitutionalist approach to judicial lawmaking recognizes that judges - like legislatures - have unbounded lawmaking authority when (and only when) they are acting within the "constitution" that sets forth the "law of lawmaking." By focusing analysis on the precise boundaries created by this constitution, this theory of judicial lawmaking reflects different aspects of a

37. See Richard B. Cappalli, The Common Law's Case Against Non-Precedential Opinions, $76 \mathrm{~S}$. CAL. L. Rev. 755, 773 (2003).

38. McCulloch v. Maryland, 17 U.S. 316, 407 (1819).

39. The American Heritage College Dictionary 483 (3d ed. 1993). 
number of legal theories including realism, formalism, positivism, legal process, and critical legal studies.

\section{A. Where Formalism and Realism Collide}

Arguably, the most basic tension in legal theory is between formalism and realism. ${ }^{40}$ At the very least, the formalist-realist dichotomy has been a vibrant aspect of legal scholarship for nearly a century. ${ }^{41}$ Formalism is typically understood as the notion that judicial lawmaking is determined by the formal requirements of the law and legal doctrine, rather than the will or desire of the particular judges applying that law. Despite the formality that it seeks to impose on the process of judicial lawmaking, formalism as a legal theory is subject to a fairly chaotic array of gradations and differing definitions. According to one commentator, "we may characterize formalism as the descriptive theory of adjudication according to which (1) the law is rationally determinate, and (2) judging is mechanical. ${ }^{42}$ Others have defined formalism in terms of decisionmaking according to rules,${ }^{43}$ emphasizing that the rules serve to "screen[] off from a decisionmaker factors that a sensitive decisionmaker would otherwise take into account." ${ }^{\text {"4 }}$ Still others have emphasized that formalism views the law as being subject to pure logical analysis of the relevant legal sources, which enables the "correct" result to be achieved through sheer deduction. ${ }^{45}$ As one commentator explains:

40. Commentators have analyzed a wide variety of legal issues by juxtaposing "formalist" and "realist" perspectives. E.g., Barry Cushman, Formalism and Realism in Commerce Clause Jurisprudence, 67 U. Chi. L. Rev. 1089 (2000); Richard Delgado, First Amendment Formalism is Giving Way to First Amendment Legal Realism, 29 Harv. C.R.-C.L. L. Rev. 169 (1994); Richard A. Posner, Legal Formalism, Legal Realism, and the Interpretation of Statutes and the Constitution, 37 CASE W. RES. L. REV. 179 (1987).

41. E.g., Karl N. Llewellyn, Some Realism About Realism—Responding to Dean Pound, 44 HaRv. L. REV. 1222 (1931).

42. Brian Leiter, Positivism, Formalism, Realism, 99 Colum. L. Rev. 1138, 1145 (1999) (reviewing Anthony Sebok, Legal Positivism in American Jurisprudence (1998)).

43. Paul N. Cox, An Interpretation and (Partial) Defense of Legal Formalism, 36 InD. L. Rev. 57, 68 (2003) ("Another understanding of formalism is that the law consists, or should consist of rules.") (citing Larry Alexander, "With Me, It's All er Nuthin": Formalism in Law and Morality, 66 U. CHI. L. Rev. 530 (1999)); Frederick Schauer, Formalism, 97 Yale L.J. 509, 510 (1988) ("At the heart of the word 'formalism,' in many of its numerous uses, lies the concept of decisionmaking according to rule.").

44. Schauer, supra note 43, at 510 ("Formalism is the way in which rules achieve their 'ruleness' precisely by doing what is supposed to be the failing of formalism: screening off from a decisionmaker factors that a sensitive decisionmaker would otherwise take into account.").

45. Cox, supra note 43 , at 60 (stating that classical formalists "believed that the result would be a self-contained, internally consistent, systemized and rationalized law, rather like geometry, and, therefore, that correct legal answers could be given to any question by reference to the logic of this system"); John 
Pure formalists view the judicial system as if it were a giant syllogism machine, with a determinate, externally-mandated legal rule supplying the major premise, and objectively "true" pre-existing facts providing the minor premise. The judge's job is to act as a highly skilled mechanic with significant responsibility for identifying the "right" externally-mandated rule, but with little legitimate discretion over the choice of the rule. ${ }^{46}$

Realism, on the other hand, endorses the view that judges are relatively unconstrained by the formal requirements of law and legal doctrine. Thus, judges may make decisions - either consciously or unconsciously_according to their personal, political, or ideological preferences. ${ }^{47}$ Or judges may "reach decisions based on what they think would be fair on the facts of the case, rather than on the basis of the applicable rules of law." 48 While they must ultimately craft their decisions in terms of legal rules and reasons, these amount to little more than "post-hoc rationales for decisions reached on other grounds. ${ }^{\circ 9}$

Hasnas, Back to the Future: From Critical Legal Studies Forward to Legal Realism, or How Not to Miss the Point of the Indeterminacy Argument, 45 DukE L.J. 84, 87 (1995) (stating that according to formalism, "judicial decisionmaking was viewed as 'a scientific, deductive process by which preexisting legal materials subsume particular legal cases under their domain, thus allowing judges to infer the antecedently existing right answer to the case at bar'”) (quoting Raymond A. Bellotti, Justifying Law: The Debate over Foundations, Goals, And Methods 4 (1992)); Posner, supra note 40, at 181 ("[Formalism is] the use of deductive logic to derive the outcome of a case from premises accepted as authoritative. Formalism enables a commentator to pronounce the outcome of the case as being correct or incorrect, in approximately the same way that the solution to a mathematical problem can be pronounced correct or incorrect.").

46. Burt Neuborne, Of Sausage Factories and Syllogism Machines: Formalism, Realism, and Exclusionary Selection Techniques, 67 N.Y.U. L. Rev. 419, 421 (1992).

47. DWORKIN, supra note 11, at 3 (noting that according to realists, "judges actually decide cases according to their own political or moral tastes, and then choose an appropriate legal rule as a rationalization")( quoted in Brian Leiter, Rethinking Legal Realism: Toward a Naturalized Jurisprudence, 76 TEX. L. Rev. 267, 267 n.1 (1997)); Hasnas, supra note 45, at 89

[The realists] implied that the rules of law could not constrain judges' choices since it was the judges who chose which rules to apply and how to apply them. Further, since such choices were necessarily based on the judges' beliefs about what was right, it was the judges' personal value judgments that consciously or unconsciously formed the basis of their decisions.

Edward L. Rubin, The New Legal Process, the Synthesis of Discourse, and the Microanalysis of Institutions, 109 HARV. L. REV. 1393, 1395 (1996) ("[T] he realists maintained that general legal principles do not exist: law is always the creation of some specific lawmaker, whether legislator, administrator, or judge, and it usually reflects the policy predilections of that lawmaker."); Joseph William Singer, Legal Realism Now, 76 Cal. L. Rev. 467, 470 (1988) (reviewing Laura Kalman, Legal Realism at Yale: 1927-1960 (1988)) ("Social context, the facts of the case, judges' ideologies, and professional consensus critically influence individual judgments and patterns of decisions over time.").

48. Leiter, supra note 47 , at 275.

49. Leiter, supra note 42 , at 85 ; see also Leiter, supra note 47 , at 268

According to what I will call the "Received View," Legal Realism is fundamentally: (1) a descriptive theory about the nature of judicial decision, according to which, (2) judges exercise 
From the realist perspective, our legal system enables such extra-legal decisionmaking because the formal requirements of law are indeterminate..$^{50}$ "[T]he Realists based their argument for indeterminacy in law primarily on the existence of conflicting, but equally legitimate, interpretive methods: for example, conflicting ways of reading statutes, or of construing precedents." ${ }^{1}$ This indeterminacy allows judges to make law however they see fit, knowing that some legal rule or reason exists that will support it. ${ }^{52}$ Even if one assumes that judges do not affirmatively intend to impose their personal views when deciding cases, the fact remains that the formal legal sources do not necessarily yield "a unique decision." 53

Philip Bobbitt's view of constitutional interpretation illustrates this point well. Bobbitt identified six "modalities" of constitutional argument: historical, textual, structural, doctrinal, ethical, and prudential. ${ }^{54}$ The requirement that constitutional argument fit within one of these six modalities

unfettered discretion, in order (3) to reach results based on their personal tastes and values, which (4) they then rationalize after-the-fact with appropriate legal rules and reasons.

50. Hasnas, supra note 45 , at 85 (noting the realists' argument that "Anglo-American law is indeterminate; that the rules of law do not compel judges to decide cases one way rather than another"); Anthony Kronman, The Crisis in Legal Theory and the Revival of Classical Jurisprudence: Jurisprudential Responses to Legal Realism, 73 CORnell L. Rev. 335, 335 (1988)

[Realists] drew the conclusion that there is - most obviously in hard cases, but in the easy cases that judges decide as well - a space or gap between all of the available legal materials that might be brought to bear in the decisional process (rules, principles, policies, and so on) and the decision itself. That space, they said, can only be filled by an arbitrary exercise of judicial will — by a choice, a decision, a judgment which is not constrained or controlled by the relevant legal rules and other norms but that must be free, even radically free, on certain views of the problem.

Leiter, supra note 47, at 273-74 (noting the realists' indeterminacy argument, but explaining that it is different from the indeterminacy argument raised by the critical legal studies movement).

51. Leiter, supra note 47, at 273 (citing K.N. Llewellyn, The BrAmBle Bush 72-75 (1930); Karl Llewellyn, Remarks on the Theory of Appellate Decision and the Rules or Canons About How Statutes Are to Be Construed, 3 VAND. L. REV. 395, 399-406 (1950)); see also Singer, supra note 47, at 470 ("[Realists] argued that legal rules were often vague and therefore ambiguous. Since these rules often contained abstract and contestable concepts, such as 'reasonableness,' 'duress,' 'title,' or 'privity of estate,' they were subject to broad interpretation. Reasonable persons could disagree about what these concepts meant; thus judges could not apply them mechanically.").

52. Singer, supra note 47 , at 470 ("[T] abstract concepts and the manipulability of precedent, it was almost always possible to appeal to competing and contradictory rules to decide any interesting contested case.") (citing Andrew Altman, Legal Realism, Critical Legal Studies, and Dworkin, 15 PHIL. \& PuB. AfF. 205, 208-09 (1986)); see also Hasnas, supra note 45, at 88 ("[T] he law is riddled with contradictory rules such that a judge will always have a choice between 'competing rules leading to opposing outcomes."') (quoting Altman, supra at 209 (citing Llewellyn, supra note 41, at 1252)).

53. Leiter, supra note 47, at 274; see also Singer, supra note 47, at 470 ("[T] he realists argued that judges could not determine, in a nondiscretionary way, the holdings of decided cases.").

54. Philip Bobbitt, Constitutional Interpretation 12-13 (1991). 
could be characterized as a formalistic requirement. But, Bobbitt recognizes that these modalities typically will not point toward a single result and, therefore, the deciding factor will inevitably be the judge's private conscience. ${ }^{55}$ Put more cynically, anything is possible with five votes in the Supreme Court. ${ }^{56}$

The normative implications of realism are not entirely clear. Some have gone so far as to say that legal realism as conventionally understood is utterly meaningless as a legal philosophy. ${ }^{57}$ Others, however, have read realism as embracing a normativity of "functionalism," 58 by which judicial decisionmaking is evaluated in terms of the actual effects of such decisions on society. ${ }^{59}$ Judge Posner, for example, defines realism as "deciding a case so that its outcome best promotes public welfare in nonlegalistic terms; it is policy analysis. ${ }^{\circ 0}$

55. Id. at 168 .

56. Antonin Scalia, The Rule of Law as a Law of Rules, 56 U. CHI. L. Rev. 1175, 1185 (1989).

57. Leiter, supra note 47, at 274 ("Within Anglo-American jurisprudence, Realism remains a joke, viewed simply as a movement that appealed to philosophically superficial lawyers, but which made no substantial contribution to philosophical thinking about law."). Note, however, that Leiter has attempted to articulate a more meaningful form of legal realism, one which would endorse "philosophical pragmatis $[\mathrm{m}]$ " and articulate a theory of adjudication that will enable lawyers "to predict what courts will do." Id. at 309 .

58. Singer, supra note 47, at 468 ("First, [legal realism] is a form of functionalism or instrumentalism."); see also Schauer, supra note 43, at 537 ("Understanding the way in which rules truncate the range of reasons available to a decisionmaker helps us to appreciate the distinction between formalism and functionalism, or instrumentalism.").

59. Hasnas, supra note 45 , at $89-90$ ("With regard to theory, they believed it demanded a redirection of study away from the logical relationships among the abstract rules of law and toward the actual effects of law and judicial decisionmaking on society."); $i d$. at 110 ("The realist would contend that in order to evaluate the desirability of any legal provision, one must descend from the realm of political abstraction to the world of the empirically verifiable and do the hard work of determining what effects that provision actually produces."); Singer, supra note 47, at 468 ("The original realists sought to understand legal rules in terms of their social consequences.") (citing Kalman, supra note 47, at 3); see also Kronman, supra note 50 , at 337

The second phase of the scientific branch of realism sought to supply, again from a point of view outside the law, the normative guidance which the critical or negative side of realism had made clear was unavailable from within the law itself. . . . In deciding cases, judges have all sorts of legal norms on which to draw, but often (perhaps, indeed, in every case) these norms run out; they fail to provide the guidance they pretend to. We must therefore look elsewhere for instruction. Where should we look? We should look, McDougal said, to the higher and more comprehensive discipline of political philosophy. (citing Lasswell \& McDougal, Legal Education and Public Policy: Professional Training in the Public Interest, 52 YALE L.J. 203 (1943)).

But see Leiter, supra note 47, at 303 ("If the Realists are pragmatists, it had better be in a sense more interesting than this.").

60. Posner, supra note 40 , at 181

By "realism" I mean deciding a case so that its outcome best promotes public welfare in 
Formalists, however, had their own responses to the insights of legal realism. As a descriptive matter, the realist notion that judges do whatever they want provides little guidance for practitioners or scholars. It is, essentially, a tautology. ${ }^{61}$ From a normative standpoint, formalists argue that the realists' mode of judicial decisionmaking exceeds the judge's proper role. To endorse the notion that judges should be making decisions based on their subjective evaluation of the consequences of possible outcomes is to displace the role of democratically elected legislatures with the whims and ideologies of individual, unelected judges.

But formalism does not necessarily provide adequate solutions to these problems either. If formalism states that the law - and not the judges who interpret and apply the law-determines the outcomes of cases, then its accuracy as a descriptive tool is highly suspect. Reasonable judges apply the law in different ways. A particular case may generate majority opinions, concurring opinions, and dissenting opinions - each of which may provide a principled, coherent analysis of the relevant legal principles. Although formalism purports to take the normative high ground by dismissing the notion that judges should be guided by extra-legal considerations, there is considerable dispute about what "forms" should be dispositive in such lawmaking. For example, both Antonin Scalia and Ronald Dworkin are considered to be formalists, but few would surmise that the two would reach the same decision in every particular case. ${ }^{62}$ Whereas Justice Scalia's formalism would require judges to apply originalist principles (at least to questions of constitutional interpretation) ${ }^{63}$ Professor Dworkin's formalism "has a richer picture of the class of legal reasons" that judges must consider. ${ }^{64}$

The formalist-realist debate helps to illustrate the value of a constitutionalist theory of judicial lawmaking. Take the classic hypothetical,

nonlegalistic terms; it is policy analysis. A "realist" decision is more likely to be judged sound or unsound than correct or incorrect - the latter pair suggests a more demonstrable, verifiable mode of analysis than will usually be possible in weighing considerations of policy.

61. See Leiter, supra note 47 , at 270

For example, according to the [Realists'] Predictive Theory, a judge who sets out to discover the "law" on some issue upon which she must render a decision is really just trying to discover what she will do, since the "law" is equivalent to a prediction of what she will do! (paraphrasing H.L.A. HART, THE CONCEPT OF LAW 141-47 (1961).

62. See Leiter, supra note 42, at 1146 (describing Professor Dworkin as a "sophisticated formalist"); Sosa, supra note 28, at 927 (describing Justice Scalia's defense of formalism).

63. See Antonin Scalia, Originalism: The Lesser Evil, 57 U. Cin. L. Rev. 849 (1989).

64. Leiter, supra note 42, at 1146; see also Hasnas, supra note 45, at 94-95; Christopher J. Peters, Foolish Consistency: On Equality, Integrity, and Justice in Stare Decisis, 105 YALE L.J. 2031, 2073-74 (1996). 
employed by Professors Hart, Fuller and Schauer, of a statute prohibiting "vehicles" in a public park. ${ }^{65}$ Would such a statute prohibit a bicycle in the park? ${ }^{66}$ Would it prohibit an electric golf cart, as quiet as a bicycle, incapable of proceeding at greater than ten miles per hour, and emitting no noxious fumes? ${ }^{67}$ Would it prohibit a statue of a truck placed in the park as a war memorial by a group of patriotic citizens? ${ }^{68}$ Under a formalist reading of this rule all of these "vehicles" would likely be prohibited. But under a realist or functionalist view, such a literal application of the rule might not serve the rule's underlying purposes, such as reducing noise, odors, or danger to pedestrians. ${ }^{69}$

The constitutionalist theory acknowledges that, whatever one thinks of the realist or formalist approaches to this problem, a court will make law regardless of which approach it chooses. If the court decides that "no vehicles" prohibits the bicycle, or the golf cart, or the truck statue, then that is the law. If the court decides that one or more of these are permitted in the park, then that is the law. We can say that the first is formalist and the second is realist, and we can argue that one is better than the other, but none of these insights impact whether that act of judicial lawmaking is effective. The fact remains that the court has the freedom to be either realist or formalist. The key question from the constitutionalist perspective is, where does that freedom end? It ends when the court transgresses the constitutional rules of judicial lawmaking, just as a legislature's freedom to make law ceases when the act of lawmaking exceeds the legislature's constitutional authority.

Thus, the constitutionalist theory of judicial lawmaking recognizes that both formalism and realism have their place, but seeks to define the true boundary between the two. There are certain areas where judges have wide discretion to decide cases how they see fit, without meaningful formal constraints that would invalidate law made within this sphere. But the boundaries of the sphere itself - the constitutional limits on judicial lawmaking-are meaningful formal constraints. Attempts at judicial lawmaking that exceed those boundaries may be treated as ineffective (i.e., unconstitutional).

65. Schauer, supra note 43, at 524 (citing H.L.A. Hart, Positivism and the Separation of Law and Morals, 71 HaRV. L. Rev. 593, 607 (1958)).

66. Id. at 514

67. Id. at 545 .

68. Id. (citing Lon L. Fuller, Positivism and Fidelity to Law-A Reply to Professor Hart, 71 HARV. L. Rev. 630, 663 (1958)).

69. See id. at 517,545 . 
It could be stated that the constitutionalist theory of judicial lawmaking is by definition anti-formalist, because it admits that judges perform a lawmaking function. Some have drawn the following distinction between formalism and realism: formalists believe that judges "find" the law, and realists believe that judges "make" the law. ${ }^{70}$ But even this view of formalism is consistent with the notion that judges perform a lawmaking function. Regardless of whether judges "find" or "make" law, it cannot be disputed that the resulting decision makes law in the sense that its holding is binding on future courts. ${ }^{71}$ Even formalists acknowledge that judicial decisions create law by virtue of stare decisis. Justice Scalia - in fact - argues that the rule of law obligates judges to formulate legal principles that will bind future tribunals. $^{72}$ Thus, the essential dispute between realists and formalists concerns not whether judges make law, but how judges decide what law to make.

\section{B. Other Schools of Legal Theory}

The constitutionalist theory of judicial lawmaking incorporates aspects of other leading legal theories as well. One of the schools that emerged as a synthesis of formalism and realism was the legal process school. ${ }^{73}$ This theory places great emphasis on the institutional competence of the judiciary and

70. Hasnas, supra note 45, at 89 ("The purpose of the [legal realists'] indeterminacy argument was to demonstrate that the formalist image of the judge as one who does not make law, but impersonally discovers and applies antecedently existing law, was a myth."); see also Cox, supra note 43, at 91 (noting "legal realism's positivist fixation on the judge as a declarer, rather than a follower, of law"); Richard H. Fallon, Jr. \& Daniel J. Meltzer, New Law, Non-Retroactivity, and Constitutional Remedies, 104 HaRv. L. REV. 1733, 1758, 1794 (1991); Neuborne, supra note 46, at 419; Singer, supra note 47, at 474 ("The legal realists wanted to replace formalism with a pragmatic attitude toward law generally. This attitude treats law as made, not found.").

71. E.g., Scalia, supra note 56, at 1176-77 ("In a judicial system such as ours, in which judges are bound, not only by the text of code or Constitution, but also by the prior decisions of superior courts, and even by the prior decisions of their own court, courts have the capacity to 'make' law."). Even Dworkin, another formalist, acknowledges this fact, though he dismisses it as a "trivial" observation. But cf. RonALD DWORK IN, LAW's EMPIRE 6 (1986) (“'In a trivial sense, judges unquestionably 'make new law' every time they decide an important case.").

72. Scalia, supra note 56, at 1176 (preferring the establishment of general rules by judges rather than allowing judges "personal discretion to do justice"); $i d$. at 1178-80 ("Much better, even at the expense of the mild substantive distortion that any generalization introduces, to have a clear, previously enunciated rule that one can point to in explanation of the decision. . . . Only by announcing rules do we hedge ourselves in."). Id. at 1180.

73. Rubin, supra note 47, at 1395 ("The success of the legal process movement stemmed from its ability to synthesize the insights of the realists with the aspirations of the formalists. It began by acknowledging, as the realists insisted, that all law is derived from political decisions."). 
other lawmaking institutions. ${ }^{74}$ To avoid encroaching on democratically elected bodies, the judiciary must refrain from acting "as a naked power organ." 75 Rather, judges must decide based on "neutral principles," that is, they must justify their decisions with "reasons that in their generality and their neutrality transcend any immediate result that is involved." "T6 Thus, the legal process school strives to analyze judicial action with reference to the judiciary's "particular preserve" and "politically granted role articulated in the Constitution." 77 The constitutionalist theory of judicial lawmaking has a similar emphasis, in that it attempts to define and analyze the precise scope of the judiciary's "particular preserve" by delineating the true boundaries of the judicial lawmaking function.

Although consistent with the legal process school in some respects, the constitutionalist theory also embraces one of the principal rivals of legal process theory - critical legal studies (CLS). CLS's main critique of the legal process school is that there are no truly "neutral principles." judges have enough neutral principles at their disposal to reach results based on political, ideological, or otherwise non-neutral reasons. ${ }^{79}$ The constitutionalist theory recognizes that courts still make law even when they act based on non-neutral principles or are motivated by non-neutral reasons, so long as they act within the constitutional principles that govern judicial lawmaking.

Because it contains aspects of both legal process and CLS, the constitutionalist theory fits nicely with one recent attempt to reconcile these two divergent schools of legal theory. Edward Rubin argues that legal process and CLS can be synthesized by concentrating legal inquiry on "microanalysis of institutions." ${ }^{80}$ Such microanalysis can provide the basis for criticizing and understanding lawmaking and law-applying institutions. My analysis of

74. Id. at 1396.

75. Hasnas, supra note 45, at 93 (quoting Herbert Weschler, Toward Neutral Principles of Constitutional Law, 73 HARV. L. Rev. 1, 19 (1959)).

76. Id. (quoting Weschler, supra note 75, at 19); see also William N. Eskridge, Jr. \& Philip P. Frickey, The Making of the Legal Process, 107 HARV. L. Rev. 2031, 2042-43 (1994); Singer, supra note 47 , at 507 .

77. Rubin, supra note 47 , at 1397.

78. Id. at 1400 .

79. Hasnas, supra note 45 , at 88 ; Singer, supra note 47 , at 470.

80. Rubin, supra note 47, at 1425; Edward L. Rubin, Legal Reasoning, Legal Process and the Judiciary as an Institution, 85 CAL. L. Rev. 265, 266 (1997) (reviewing Cass R. Sunstein, Legal Reasoning and Political Conflict (1996)) [hereinafter Rubin, Legal Reasoning]. 
judicial lawmaking's constitution is an attempt to microanalyze the true boundaries of judicial lawmaking authority. ${ }^{81}$

Finally, the constitutionalist theory is consistent with legal positivism. A bedrock principle of positivism is that "[w]hat counts as law in any particular society is fundamentally a matter of social fact." Positivism thus focuses on society's "rules of recognition" for identifying valid acts of lawmaking. ${ }^{82}$ Constitutionalism is in many ways a positivistic concept, because it seeks to define the rules that govern how law is made. The rules of recognition inherent in any positivist legal system are, essentially, a constitution. As Frank Michelman recently wrote:

Positive legal ordering implies a constitution. To think the one is to suppose the other. There cannot be ordering by positive law (i.e., by the law-declaring and law-applying pronouncements of socially recognized legal officialdom who can count on society to back them up by force if necessary), where a territory's inhabitants do not broadly converge on recognition of which persons, acting by what forms and procedures, count as legal officials. So if what and all you want to mean by "constitution" is a country's existing, socially shared sense of the organization of legal authority, then constitution is an idea you cannot refuse, at least not without a more thoroughgoing rejection of positive legal ordering than you probably will find tolerable. Any positively legally ordered country has what we may call its inevitable constitution." ${ }^{83}$

The constitutionalist theory seeks to articulate and analyze the "inevitable constitution" that governs the judicial lawmaking function.

\section{The Normativity of the Constitutionalist Theory}

The constitutionalist view of judicial lawmaking is normatively neutral about the precise content of judicial lawmaking's constitution. Just as formalists can disagree about which formalistic norms should govern a particular legal issue, constitutionalists can disagree about which constitutional principles should limit the scope of judicial lawmaking. After all, those who study constitutional law (in the traditional sense) have sharp disputes over what constitutional law should or should not be. This article seeks to articulate the concept of a constitution for judicial lawmaking,

81. Rubin, Legal Reasoning, supra note 80, at 266 (“[W]hat is needed for a revitalization of legal process analysis, as opposed to a mere revival, is a microanalysis of the judiciary as an institution."); $i d$. at 283 ("Microanalysis also suggests that we explore the authority structure of the judiciary in greater detail.").

82. Leiter, supra note 42 , at 1141-42.

83. Michelman, Judicial Supremacy, note 10, at 588 (emphasis added). 
describe that constitution as it currently exists,${ }^{84}$ and thereby commence the normative debate about the scope and content of this constitution.

The constitutionalist theory does, however, have normative implications for legal theorists and others who opine on judicial lawmaking. The constitutionalist theory urges those with proposals to reform the judicial lawmaking function to address specifically whether those proposals should impact the constitutional boundaries of judicial lawmaking. Because the constitutionalist theory recognizes that judges are free to make law as they see fit when acting within the boundaries set by this constitution, proposals that do not implicate judicial constitutional limits will—by necessity-leave judges free to ignore them.

Thus, those with normative theories about judicial lawmaking should strive to address whether the principles they espouse should be constitutional principles that limit the scope of effective judicial lawmaking. For example, it is one thing to argue that originalism should be the dominant interpretive tool in deciding the meaning of the United States Constitution. ${ }^{85}$ It is another thing to argue that a court's failure to employ originalism when interpreting the Constitution should be grounds for treating that court's act of lawmaking as ineffective. ${ }^{86}$

Adopting a constitutional perspective on judicial lawmaking and legal theory thus provides an important metric for evaluating and understanding proposals in the area of jurisprudence and the judiciary's lawmaking role. By no means do I intend to suggest that theories are not helpful unless they propose constitutional reform for judicial lawmaking. Such theories are illuminating, of course. They help to distinguish good judicial lawmaking from bad judicial lawmaking, and they may even persuade judges to approach their lawmaking role in a different way. But unless a theory implicates the constitution of judicial lawmaking, it will not impact the court's discretion to act within the bounds of its authority to make law however it sees fit.

84. In this sense, the constitutionalist approach is a descriptive endeavor, seeking to identify the rules of judicial lawmaking that truly govern whether a particular act of judicial lawmaking is effective. See Dennis Patterson, Conscience and the Constitution, 93 Colum L. Rev. 270, 295 (1993) (reviewing BoB BIT, supra note 54) ("[T] he essential task of jurisprudence is the accurate description of our legal practices of argument and justification.”).

85. Scalia, supra note 63, at 862 .

86. Patterson, supra note 84, at 298 ("Bork was stating forth-rightly that the weight of precedent could be ignored and, if found wanting by the measure of an originalist yardstick, overturned.") (citing BobBitT, supra note 54, at 93 (quoting Nomination of Robert H. Bork to be Associate Justice of the Supreme Court of the United States: Hearings Before the Senate Comm. on the Judiciary, 100th Cong., 1st Sess. 104, at $370(1987)))$. 
The distinction I draw is similar to the distinction in the legislative context between public policy analysis and constitutional analysis. ${ }^{87}$ Public policy analysis is unquestionably valuable, but it does not speak to the legislature's authority to make bad policy if it decides to do so. Constitutional analysis, on the other hand, examines the limits on a legislature's policymaking authority. Likewise, the constitution of judicial lawmaking deserves separate consideration.

In order to avoid any misunderstanding, let me make explicit the following caveat. Endorsing a constitutionalist theory of judicial lawmaking is not tantamount to conceding that judicial lawmaking and legislative lawmaking are or should be the same. The constitutionalist approach does, of course, accept the fact that judges, much like legislators, have wide discretion to make law as they see fit so long as they comply with the constitutional limits on their authority. That does not mean that judges should behave like legislators, however. There is a difference between good judicial lawmaking and bad judicial lawmaking, and judges should endeavor to make law that is coherent, principled, and considerate of the relevant legal sources ${ }^{88}$ But even bad judicial decisions can still be effective acts of lawmaking, and any meaningful theory should recognize that fact.

Moreover, those who cringe at comparing judicial lawmaking to legislative lawmaking may want to consider whether they are cutting legislators too much slack. We do - or at least we should — draw distinctions between good and bad legislative lawmaking. All statutes are not normatively

87. See, e.g., Paul W. Kahn, The Court, the Community and the Judicial Balance: The Jurisprudence of Justice Powell, 97 YALE L.J. 1, 14 (1987) ("Local schools may ... represent good public policy, but there is no constitutional right to attend a local community school."); Lino A. Graglia, The Burger Court and Economic Rights, 33 TuLsA L.J. 41, 44 (1997) (“[G]ood constitutional law can permit very bad social policy."). Admittedly, this distinction is not always drawn very sharply. See Stephen L. Carter, The Confirmation Mess, Revisited, 84 Nw. U. L. REv. 962, 963 (1990) ("Strive though we might, few of us are able to make a complete separation between our views about good public policies and our views about constitutional meaning."); Mark Tushnet, The Canon(s) of Constitutional Law: An Introduction, 17 Const. Comment, 187, 191-92 (2000) (noting law school teaching techniques that "intend[] to help students think about the difference (if any) between constitutional law and good public policy").

88. In this way, legislative and judicial lawmaking should — and typically do—operate differently. See Balkin \& Levinson, supra note 5, at 1078

[Judges] are constrained by the expectations of what well trained lawyers can say and cannot say, the language of legal doctrines, the received forms and modalities of legal argument, the need to give reasons for their decisions, and their inability to perform legislative tasks like appropriating monies or going to war. So judges who extend partisan influence over time clearly cannot do everything that legislatures can do. But they can do a great deal, and if you give them enough time, they will make significant changes. 
desirable simply because they passed both houses of Congress and were signed by the President. Even so, we recognize that bad statutes are still effective acts of lawmaking as long as they comply with the requirements set by the Constitution.

Of course, legislators arguably should be allowed more discretion, as they are subject to regular elections, whereas judges - or federal judges, anyway - are appointed for life. ${ }^{89}$ This is an important distinction, but it is not as stark as it might appear at first blush. As Jack Balkin and Sanford Levinson noted recently, there is a link between the makeup of the judiciary and the will of the people, as judges and justices are chosen by the President and reviewed by the Senate. Comparing Supreme Court Justices to Senators appointed to an eighteen year term, ${ }^{90}$ they point out that "if you don't like what the Court is doing now, you (or your parents) shouldn't have voted for Ronald Reagan." ${ }^{91}$ Admittedly, the eighteen year figure is considerably longer than any elected official's single term of office. But in light of the inherent advantages that accrue to elected incumbents, ${ }^{92}$ the legislative and executive branches may not be quite as malleable to the will of the people as conventional theory might suggest.

To the extent I equate judicial and legislative lawmaking, it is simply to state this point: For both judicial and legislative lawmaking, there are two separate questions: The first is, how do we evaluate whether the lawmaking is normatively good or bad? The second is, what are the outer boundaries that define whether an attempt at lawmaking - good or bad-is effective? In the context of judicial lawmaking, the legal academy has devoted a great deal of attention to the first question, but has not made a conscious effort to tackle the

89. Larry W. Yackle, Choosing Judges the Democratic Way, 69 B.U. L. Rev. 273, 286 (1989). Mainstream American legal thinking distinguishes primarily representative governmental bodies (like legislatures) from primarily judgmental institutions (like courts). Thus while it may be acceptable on occasion to explain that legislators are elected on the ground that their function is to substitute for the public at large, the same contention cannot be made respecting judges, who are not supposed to represent anyone. Judges make law, to be sure, but they do not vindicate the perceived aggregate preferences of the electorate; they do not serve as surrogates for a majority of citizens who, if asked, might decide cases by a nose count.

90. Balkin \& Levinson, supra note 5, at 1067 \& n.104 ("On average, Supreme Court Justices serve about eighteen years. In this sense, judges and Justices resemble Senators who are appointed for 18-year terms by their parties and never have to face election.").

91. Id. at 1076 .

92. See Akhil Reed Amar, Philadelphia Revisited: Amending the Constitution Outside Article V, 55 U. CHI. L. Rev. 1043, $1081 \&$ nn.135-37 (1988) (noting that "the average tenure of a senior Congressman is even longer than that of the average Supreme Court justice") (citing Philip Bobbitt, Constitutional Fate, 58 TEX. L. Rev. 695, 754 n.238 (1980)). 
second question. By describing and analyzing the constitution that governs judicial lawmaking, this article is a first step toward identifying this second question and bringing it to the forefront.

\section{A Constitution Without Text?}

One potential criticism of the constitutionalist approach to judicial lawmaking is obvious: How can one speak of a constitution for judicial lawmaking where that constitution does not exist in any concrete textual form? Judicial lawmaking's constitution is, in this sense, quite different from our conventional understanding of constitutionalism. Constitutional law is what it is because it stems from a specific document - a constitution (whether state or federal).

However, many have recognized that substantial portions of our constitutional law (as typically understood) are, in fact, unwritten. Even though many well-established constitutional principles may be grounded in a particular constitutional provision, it is not necessarily the text that is "supplying the norms that guide decision." the argument that we do, in fact, have an unwritten constitution, which supplements the written one. ${ }^{94}$

On this point, it is again instructive to cite Philip Bobbitt's view of constitutional interpretation. Bobbitt identified six "modalities" of constitutional argument - historical, textual, structural, doctrinal, ethical, and prudential — and argued that constitutional argument is legitimate as long as it employs one or more of these modalities. ${ }^{95}$ The text, according to Bobbitt, is only one of six modalities that comprise legitimate constitutional argument. The remaining five, therefore, could be used without any textual source. So too can non-textual arguments be used in analyzing judicial lawmaking's implicit constitution. (1988).

93. Thomas C. Grey, The Uses of an Unwritten Constitution, 64 CHI.-Kent L. Rev. 211, 221-22

94. See id.; Thomas C. Grey, Do We Have an Unwritten Constitution?, 27 Stan. L. Rev. 703, 710-14 (1975).

95. Boввітт, supra note 54, at 12-13. 


\section{E. Practical Implications}

A deeper understanding of the constitutional rules of judicial lawmaking is also important for practitioners. ${ }^{96}$ The oldest quandary for litigators is what to do about the "bad case" - the one that seems directly on point and adverse to your client. Most lawyers, not to mention law students, are quite gifted at the art of distinguishing the facts of cases. But when the key obstacle is a judicial decision that establishes an adverse legal standard or rule of decision, a zealous advocate must at least consider whether that decision can be attacked as being beyond the court's lawmaking authority, i.e., as violating the implicit constitution that governs judicial lawmaking.

Just as constitutional arguments are the last refuge of clients who are adversely affected by acts of legislative lawmaking, the constitutional rules for judicial lawmaking may provide similar refuge in handling bad caselaw. Obtaining a mastery of judicial lawmaking's constitution can empower the practitioner to argue persuasively that the "bad case" is ineffective as an act of judicial lawmaking.

In the past, evaluating whether a judicial decision was an effective act of lawmaking may have been less of a concern, because the central issue for the practitioner was getting a favorable judicial ruling from this court - the one adjudicating the instant dispute. But in certain areas of the law, prevailing in court may depend not only on what the law is, but on what the law was. When an individual convicted in state court seeks federal habeas relief, he often must demonstrate that the law on which he relies had been "clearly established... by the Supreme Court of the United States" at the time his state conviction became final. ${ }^{97}$ Likewise, qualified immunity will bar a plaintiff from obtaining damages against a government official for a violation of federal law, unless she can show that the law defining the violation was "clearly established" at the time of the incident. ${ }^{98}$ These legal inquiries are, by their terms, retrospective in nature, looking back to a particular point in time and asking whether valid acts of judicial lawmaking had occurred.

96. Harry T. Edwards, The Growing Disjunction Between Legal Education and the Legal Profession, 91 Mich. L. REv. 34, 34 (1992) ("The schools should be training ethical practitioners and producing scholarship that judges, legislators, and practitioners can use.").

97. 28 U.S.C. $§ 2254(d)(1)$ (2000); see generally Adam N. Steinman, Reconceptualizing Federal Habeas Corpus for State Prisoners: How Should AEDPA's Standard of Review Operate After Williams v. Taylor?, 2001 WIs. L. Rev. 1493 (2001).

98. See Wilson v. Layne, 526 U.S. 603, 609 (1999). 


\section{The Constitution of Judicial Lawmaking in the Federal JUDICIARY}

This section describes what the implicit constitution that governs federal judicial lawmaking presently looks like. I examine four areas: (1) the judiciary's enumerated powers, particularly the holding-dictum distinction, (2) the judiciary's authority to change its law, (3) the judiciary's authority to deprive its decisions of legal effect, and (4) judicial voting. My goal here is not to address each of these areas in full detail. I will, however, explore whether these requirements are constitutional prerequisites, as I have defined the term, for judicial lawmaking.

\section{A. Enumerated Powers}

The first issue is the judiciary's enumerated powers. Just as Congress may not make law if it exceeds the enumerated powers set out in Article I, judicial lawmaking is invalid if it addresses subjects that the court is not authorized to address. For judges, the principle that mere dicta does not constitute binding precedent limits the subject matter about which a particular court may make law. Only a court's holding creates law that is prospectively binding on future legal actors.

Thus, the distinction between dicta and holdings is critical for demarcating the boundaries of effective judicial lawmaking. This distinction is part of the constitution that governs judicial lawmaking, because attempts at judicial lawmaking that are mere dicta may be treated as ineffective by subsequent tribunals: "It is to the holdings of our cases, rather than their dicta, that we must attend[.]"99 The most basic articulation of the distinction between dictum and holding is that future courts are bound by the parts of a judicial opinion that are "necessary" to reaching the result in that case. ${ }^{100}$ Thus, the Court has found portions of a prior opinion to be dicta where they were "not essential to [the] disposition of any of the issues contested ...."

99. Kokkonen v. Guardian Life Ins. Co., 511 U.S. 375, 379 (1994); see also Tyler v. Cain, 533 U.S. 656, 663 n. 4 (2001) (noting that dictum is not binding); U.S. Bancorp Mortgage Co. v. Bonner Mall P'ship, 513 U.S. 18, 24 (1994) ("This seems to us a prime occasion for invoking our customary refusal to be bound by dicta.").

100. Seminole Tribe v. Florida, 517 U.S. 44, 66-67 (1996).

101. Cent. Green Co. v. United States, 531 U.S. 425, 431 (2001). 
Beyond such general statements, however, courts have provided remarkably little guidance about the holding-dictum distinction. One established principle, however, is that when a court provides alternative holdings to support its ruling, all the alternative holdings are binding: "[W]here a decision rests on two or more grounds, none can be relegated to the category of obiter dictum." 102 Consider, for example, a court adjudicating an ineffective assistance of counsel claim under the Sixth Amendment. Such a claim has two elements: (1) "deficient performance"; that is, counsel's conduct must fall "below an objective standard of reasonableness," and (2) "prejudice"; that is, there must be a reasonable probability that the outcome would have been different had counsel performed properly. ${ }^{103}$ The court could reason that (1) the attorney did not perform deficiently, and (2) in the alternative, there was no reasonable probability that the attorney's conduct would have resulted in a different outcome. Both of these rulings constitute the court's holding, even though it could be argued that each one was not truly necessary to the court's decision.

While the established rule on the binding nature of alternative holdings is an interesting one, it does not elucidate the more fundamental question of what the holding actually is. On this point, there remains a great deal of debate. Does the holding include the rationale used by the court in reaching its decision, or does it only include the ultimate legal conclusion reached by the court on the facts of the case before it? ${ }^{104}$ When the opinion expressly articulates a rule to govern a particular legal question, is that rule necessarily part of the court's holding? ${ }^{105}$ Even if rules or rationales ordinarily constitute part of a court's holding, are all such rules or rationales binding, or may some be rendered dicta if the ultimate result could have been reached without addressing that particular issue?

Courts have provided mixed messages on these questions. In Seminole Tribe v. Florida ${ }^{106}$ the Supreme Court seemed to endorse the principle that

102. Woods v. Interstate Realty Co., 337 U.S. 535, 537 (1949).

103. Strickland v. Washington, 466 U.S. 668, 687-88 (1984).

104. For a thorough discussion of the difference between the rationale-based and facts-plus-outcomebased approaches to the holding-dictum distinction, see Michael C. Dorf, Dicta and Article III, 142 U. PA. L. REV. 1997 (1994).

105. See generally Larry Alexander, Constrained by Precedent, 63 S. CAL. L. Rev. 1, 17-28 (1989); Scalia, supra note 56, at 1176-80; Peters, supra note 4, at 401-11; Brenda Swerenga, Comment, Still Newer Equal Protection: Impermissible Purpose Review in the 1984 Tour, 53 U. CHI. L. Rev. 1454, 1466-71 (1986).

106. 517 U.S. 44 (1996). 
rationales upon which particular results are based constitute part of the court's holding:

We adhere in this case, however, not to mere obiter dicta, but rather to the wellestablished rationale upon which the Court based the results of its earlier decisions. When an opinion issues for the Court, it is not only the result but also those portions of the opinion necessary to that result by which we are bound..$^{107}$

On other occasions, however, Justices have suggested that the true holding is limited to the ultimate result reached by the court. One example of this approach is Chief Justice Rehnquist's view of Roe v. Wade, ${ }^{108}$ as expressed in his concurrence to Webster v. Reproductive Health Services. ${ }^{109}$ In Roe, of course, the Supreme Court set forth the well known framework for evaluating state regulations in the area of abortion:

(a) For the stage prior to approximately the end of the first trimester, the abortion decision and its effectuation must be left to the medical judgment of the pregnant woman's attending physician.

(b) For the stage subsequent to approximately the end of the first trimester, the State, in promoting its interest in the health of the mother, may, if it chooses, regulate the abortion procedure in ways that are reasonably related to maternal health.

(c) For the stage subsequent to viability, the State in promoting its interest in the potentiality of human life may, if it chooses, regulate, and even proscribe, abortion except where it is necessary, in appropriate medical judgment, for the preservation of the life or health of the mother. ${ }^{110}$

According to Chief Justice Rehnquist, this language in Roe is not actually its holding. ${ }^{111}$ He criticized the Roe opinion for "purport[ing] to adopt a whole framework, complete with detailed rules and distinctions, to govern the cases in which the asserted liberty interest would apply." 112 Chief Justice Rehnquist expressly distinguished the "opinion" in Roe from its "holding," 113 and ultimately concluded that "the holding of Roe ... was that the Texas statute unconstitutionally infringed the right to an abortion derived from the Due Process Clause[.]"114 Since the Texas statute at issue in Roe criminalized

107. Id. at 66-67.

108. Roe v. Wade, 410 U.S. 113 (1973).

109. Webster v. Reprod. Health Servs., 492 U.S. 490 (1989).

110. Roe, 410 U.S. at $164-65$.

111. See Dorf, supra note 104, at 2008-09; Thomas L. Fowler, Of Moons, Thongs, Holdings and Dicta: State v. Fly and the Rule of Law, 22 CAmpBell L. Rev. 253, 309 n.206 (2000).

112. Webster, 492 U.S. at 520.

113. Id. (" $[\mathrm{T}]$ he opinion, if not the holding, of Roe v. Wade ... sought to establish a constitutional framework for judging state regulation of abortion during the entire term of pregnancy.").

114. Id. at 521 . 
abortions in all circumstances unless the mother's life was at stake, ${ }^{115}$ this would be a narrow reading indeed in terms of Roe's lawmaking effect. Applying Rehnquist's approach more generally, a court's holding would be narrowed simply to the ultimate result reached by the court. ${ }^{116}$

Here is another interesting facet of the dicta-holding distinction. Some courts have indicated that rulings on important threshold questions (such as the standard of review governing a particular issue) may be rendered dicta if, after proceeding beyond the threshold question, the same result would have been reached regardless of how the threshold question was decided. The Second Circuit case of Washington v. Schriver ${ }^{117}$ is an example of this. This case concerned a state defendant's writ of habeas corpus challenging his state conviction on the basis that the exclusion of evidence from his criminal trial violated his federal constitutional rights. It also presented an important question regarding 28 U.S.C. $\S 2254(d)(1)$ 's deferential standard of review, recently imposed by the Antiterrorism and Effective Death Penalty Act (AEDPA). Under this provision, the federal court must defer to the state court's resolution of federal constitutional issues if the state court had adjudicated those issues on the merits. The question in Washington was whether AEDPA required deference where the state court failed to provide any reasoning to support its refusal to grant the defendant the requested relief. ${ }^{118}$

Originally, the Second Circuit ruled that AEDPA did not require deference where a state court fails to issue an opinion addressing the defendant's constitutional claim. ${ }^{119}$ It therefore applied a de novo standard of review to the petitioner's constitutional claim, but concluded that no violation occurred. ${ }^{120}$ Six months later, however, the Second Circuit amended its opinion. In the amended opinion, the court declined to decide whether deference was required under AEDPA, because the petitioner would not be entitled to relief even under a de novo standard. ${ }^{121}$ In a concurring opinion, Judge Calabresi reasoned:

115. Id. at $500 \mathrm{n} .1$ (citing Roe, 410 U.S. at $117-18 \&$ n.2).

116. See Dorf, supra note 104, at 2008-09; Fowler, supra note 111, at 309 n.206.

117. Washington v. Schriver, 240 F.3d 101 (2d Cir. 2001), superseded by 255 F.3d 45 (2d Cir. 2001).

118. For an argument that deference should not be required in this circumstance, see Steinman, supra note 98 , at 1493 .

119. See Washington, 240 F.3d at 108-09.

120. Id. at $110-16$.

121. Washington, $255 \mathrm{~F} .3 \mathrm{~d}$ at 55. 
[G]iven the unanimous agreement of the panel that the petitioner's claim fails even under non-deferential, pre-AEDPA review, any statement - as to which rule applies when State courts make no reference to the federal grounds for their decision - would in this case be dicta. $^{122}$

It is not clear, however, that a court's ruling on a threshold question is rendered dicta simply because the ruling on the merits would have been the same regardless of how the threshold question was resolved. ${ }^{123}$ In any event, I will revisit these issues in Part IV. For now, it suffices to say that the distinction between dicta and holdings creates a constitutional limit on judicial lawmaking. Before leaving the question of the judiciary's enumerated powers under the constitution for judicial lawmaking, it is worth asking whether there are other subject matter limits on courts' lawmaking authority. When one thinks of fundamental limits on judicial authority, after all, dicta is not usually high on the list. More commonly, notions such as jurisdiction, standing, justiciability, ripeness, or mootness would spring to mind. Surely, all of these principles restrict judicial authority. Unless the litigants have standing to sue, for example, the court may not adjudicate the dispute and, therefore, cannot make law with respect to the claims at issue. ${ }^{124}$ One could argue that these also place constitutional limits on the subject matter that courts may address when they engage in lawmaking acts.

But are these truly constitutional limits on judicial lawmaking as this article defines that term? The answer is no, for the following reason: All of these threshold questions that go to a court's authority to hear a particular case are resolved by the court itself. A court's resolution of those issues may be reviewed by a higher court, of course, and could be reversed on appeal. But once all appeals are complete, the precedential impact of the resulting opinion cannot be challenged in a later case on the grounds that, for example, the litigants in the earlier case lacked standing. Rather, it is the first court-the court whose lawmaking authority will be at issue in future cases - that decides threshold questions like standing.

122. Id. at 64 .

123. See Schiro v. Farley, 510 U.S. 222, 232-35 (1994) (holding that whether jury verdict had preclusive effect as an acquittal is subject to de novo review by federal court, even in the context of a habeas corpus petition, but agreeing with state court that jury verdict did not constitute an acquittal); Santamaria v. Horsley, 110 F.3d 1352, 1356 (9th Cir. 1997) (citing Schiro for proposition that standard of review is de novo); see also Bose Corp. v. Consumers Union, 466 U.S. 485, 514 (1984) (holding that appellate courts must independently review a lower court's finding of actual malice in the context of defamation action, but stating that the trial court's finding might also have been set aside under clearly erroneous review).

124. E.g., Lujan v. Defenders of Wildlife, 504 U.S. 555 (1992). 
Let us again use Roe v. Wade as an example. Whether the pregnant women who challenged the Texas statute had standing to sue was an important issue in that case. The case was initiated in 1970, but it did not reach the Supreme Court until 1972. Thus, the state argued that "Roe's case must now be moot because she and all other members of her class are no longer subject to any 1970 pregnancy." 125 The Supreme Court, however, found that Roe nonetheless had standing, based on the exception for conduct that was "capable of repetition yet evading review." 26 Accordingly, the Court proceeded to decide the constitutional issues presented by the Texas statute's restrictions on abortion.

As discussed above, future courts might disagree about which parts of the Roe decision are mere dicta and which constitute the Court's holding. If a future court determines that a certain part of Roe is dictum, then it need not treat that portion of Roe as effective judicial lawmaking. But it does not appear that a future court could decline to follow Roe based simply on its independent determination that the plaintiff in Roe did not, in fact, have standing to raise the issues decided in that case. Once the original lawmaking court finds that a threshold requirement like standing is met, future courts may not second guess that conclusion when deciding whether the original court's lawmaking act was effective. Unless the rules on standing, justiciability, and the like are enforceable by future courts, they do not create constitutional limits on judicial lawmaking as I define that term.

\section{B. The Judiciary's Power to Change Its Own Law}

A second issue concerns the judiciary's authority to change law it has already made. The doctrine of stare decisis limits a court's ability to change law that has already been made by a prior court. This issue is unique to the judiciary, and has no direct analogy to legislative lawmaking. ${ }^{127}$ There are no special rules that apply when Congress enacts a statute that would change, amend, or supersede a statute that it enacted previously. For judicial lawmaking, however, the doctrine of stare decisis is critical. After all, it is the fact that courts are bound to follow earlier decisions that endows judicial decisions with prospective legal force.

125. Roe v. Wade, 410 U.S. 113, 124 (1973).

126. Id. at 125 (quoting Southern Pac. Terminal Co. v. ICC, 219 U.S. 498, 515 (1911)).

127. See, e.g., Peters, supra note 64, at 2082 ("[T] he legislature's power is supersessive; when it enacts a new statutory scheme it can jettison the old one entirely."). 
It is well-accepted that a prior act of judicial lawmaking cannot be amended cavalierly. Rather, the Supreme Court has articulated the following test to determine whether a court may overrule a previous decision:

[W]hen this Court reexamines a prior holding, its judgment is customarily informed by a series of prudential and pragmatic considerations designed to test the consistency of overruling a prior decision with the ideal of the rule of law, and to gauge the respective costs of reaffirming and overruling a prior case. Thus, for example, we may ask whether the rule has proven to be intolerable simply in defying practical workability, whether the rule is subject to a kind of reliance that would lend a special hardship to the consequences of overruling and add inequity to the cost of repudiation, whether related principles of law have so far developed as to have left the old rule no more than a remnant of abandoned doctrine, or whether facts have so changed, or come to be seen so differently, as to have robbed the old rule of significant application or justification. ${ }^{128}$

The Court has also indicated that stare decisis imposes different burdens for issues of statutory construction on one hand and issues of constitutional law on the other. Generally, courts are supposed to be more deferential to their prior rulings on statutory issues than on constitutional issues, in part because Congress has the power to amend the statute if it disagrees with a particular judicial interpretation. ${ }^{129}$

Notwithstanding the different applications of stare decisis in the statutory and constitutional contexts, the principle that law may be changed only in certain circumstances is unquestionably an important rule of judicial lawmaking. But is it an enforceable constitutional principle, such that a court's disregard of that principle renders an attempt to make law ineffective? To frame this question, assume the court decides Case A. Later, the court decides Case B, which creates law that is directly in conflict with Case A. But Case $\mathrm{B}$ does not conduct the inquiry required to justify a departure from stare decisis. Is Case $\mathrm{B}$ an ineffective act of lawmaking?

If these two cases are in the Supreme Court, the answer appears to be no. That is, even if the Supreme Court changes the law without finding justification for changing the law, that subsequent act of lawmaking can still be effective. Often, the Supreme Court will simply conclude that Case B

128. Planned Parenthood v. Casey, 505 U.S. 833, 854-55 (1992) (citations omitted); see also Dickerson v. United States, 530 U.S. 428, 443 (2000) (holding that although stare decisis is "not an inexorable command," the Supreme Court has "always required a departure from precedent to be supported by some 'special justification"” (quoting Payne v. Tennessee, 501 U.S. 808, 82 8, 842 (1991))).

129. See William N. Eskridge, Jr., Overruling Statutory Precedents, 76 Geo. L.J. 1361, 1365 (1988); see also Oona A. Hathaway, Path Dependence in the Law: The Course and Pattern of Legal Change in a Common Law System, 86 IowA L. Rev. 601, 656 (2001). 
"implicitly overruled" Case A. ${ }^{130}$ At a minimum, the conflict between Case A and Case B will simply create an occasion for the Court to resolve the conflict and, thereby, choose afresh which should henceforth be the law. ${ }^{131}$

At the circuit court level, however, the principles governing changes to existing law are somewhat different, particularly because of the distinction between decisions by three-judge panels and decisions by the full en banc court. As a general matter, federal appellate panels may not overrule prior decisions of panels within that circuit. Only the en banc court may overrule the lawmaking act of a prior panel. ${ }^{132}$ Is this principle an enforceable constitutional limit on judicial lawmaking? In the Fifth Circuit, the rules governing the overruling of prior panel decisions do rise to a constitutional magnitude. Where Case B conflicts with the earlier Case A, panels are obligated to follow the earlier case unless and until it is overruled by the en banc panel. ${ }^{133}$ The Seventh Circuit, on the other hand, has taken a different approach, whereby a three-judge panel may overrule a decision of a prior panel, as long as the opinion is circulated to the other judges without objection. ${ }^{134}$ That is, Case B is an effective act of judicial lawmaking, despite its conflict with Case A, as long as it is circulated and other judges do not object.

Judicial hierarchy adds a few additional wrinkles to the judiciary's power to change its own law. As an initial matter, it raises the question of which court's law a particular court is obligated to follow. Although it is generally recognized that a court is bound by both its own decisions and decisions of superior courts, some have suggested that stare decisis should not in fact

130. E.g., Sullivan v. Boerckel, 526 U.S. 838, 853 (1999) (stating that Coleman v. Thompson, 501 U.S. 722 (1991), had implicitly overruled Moore v. Dempsey, 261 U.S. 86 (1923)).

131. See, e.g., Thomas v. Wash. Gas Light Co., 448 U.S. 261, 277 (1980) ("This history indicates that the principal values underlying the doctrine of stare decisis would not be served . . . by attempting to preserve the uneasy coexistence of Magnolia and McCartin.... We conclude that a fresh examination of the ... issue is therefore entirely appropriate.").

132. E.g., Cargill v. Turpin, 120 F.3d 1366, 1386 (11th Cir. 1997) ("The law of this circuit is 'emphatic' that only the Supreme Court or this court sitting en banc can judicially overrule a prior panel decision.”).

133. See Texaco v. La. Land \& Exploration Co., 995 F.2d 43, 44 (5th Cir. 1993) (“'In the event of conflicting panel opinions from this court, the earlier one controls, as one panel of this court may not overrule another."' (quoting Smith v. Penrod Drilling Corp., 960 F.2d 456, 459 n.2 (5th Cir. 1991))).

134. See 7TH CIR. R. 40(e):

A proposed opinion approved by a panel of this court adopting a position which would overrule a prior decision of this court or create a conflict between or among circuits shall not be published unless it is first circulated among the active members of this court and a majority of them do not vote to rehear en banc the issue of whether the position should be adopted. 
mandate adherence to superior court decisions. ${ }^{135}$ But if one accepts the premise that a superior court's decisions are binding on lower courts, the interesting question arises of whether and how an intervening decision by a superior court justifies a change in the lower court's law. ${ }^{136}$

\section{The Judiciary's Power to Deprive Its Own Decisions of Legal Effect}

The third constitutional principle I will examine is also unique to the judicial lawmaking function - what is a court's authority not to make law? Recently, federal appellate courts have issued a high percentage of so-called "unpublished" decisions ${ }^{137}$ that, according to the local rules of these courts, do not constitute binding precedent. ${ }^{138}$ The question has arisen, however, whether courts have the authority to deprive their own decisions of lawmaking effect. Although one appellate court held that Article III prohibited courts from refusing to treat its prior decisions as binding precedent, that decision was later vacated upon en banc rehearing. ${ }^{139}$ Courts have continued to issue unpublished, non-precedential decisions, and some have expressly held that this practice is constitutional. ${ }^{140}$

Several justifications are typically advanced for allowing courts to deny precedential force to their unpublished decisions. According to supporters of the practice, only cases involving a routine application of established legal principles are designated non-precedential. Because such cases, by definition,

135. See Evan H. Caminker, Why Must Inferior Courts Obey Superior Court Precedents?, 46 STAN. L. REV. 817, 820, 856-65 (1994) (noting that "the doctrine of hierarchical precedent appears deeply ingrained in judicial discourse - so much so that it constitutes a virtually undiscussed axiom of adjudication" but presenting arguments why lower courts should be allowed to defy superior court precedent).

136. Compare Gwin v. Snow, 870 F.2d 616, 627 (11th Cir. 1989) (“This panel cannot overrule our circuit's binding precedent because we lack the power as a panel to change this rule of law. Thus, we must accept this rule despite its conflict with Supreme Court precedent until our in banc court visits the issue.") with New Port Largo, Inc. v. Monroe County, 985 F.2d 1488, 1501 n.8 (11th Cir. 1993) (Edmondson, J., concurring) (" $[\mathrm{W}]$ here one of our decisions plainly contradicts a Supreme Court decision, I believe no need exists for an en banc rehearing.") (emphasis in original)

137. See Cappalli, supra note 37, at 757-58 ("[T] he number of non-precedential opinions currently outnumber by far the ones that count as authority, reaching a four-to-one ratio in the federal circuits as a whole.").

138. See, e.g., 9TH Cir. R. 36-3(a) ("Unpublished dispositions and orders of this Court are not binding precedent, except when relevant under the doctrine of law of the case, res judicata, and collateral estoppel.").

139. Anastasoff v. United States, 223 F.3d 898, 900 (8th Cir. 2000), vacated by 235 F.3d 1054 (8th Cir. 2000).

140. Hart v. Massanari, 266 F.3d 1155, 1159 (9th Cir. 2001). 
will not advance or illuminate the state of the law, judges should be able to devote their limited time and energy toward cases that will impact the content of the law in their circuit. Thus, both judges and practitioners can concentrate on the opinions that do matter-the published ones. This will enable more knowledgeable, effective advocacy by lawyers and allow judges to keep the law clear and consistent. ${ }^{141}$

Nonetheless, many commentators have criticized courts' increased use of non-precedential opinions. ${ }^{142}$ After all, if the true reason for issuing an unpublished decision is that no new law is created, then no conflict or confusion should result if they are published. ${ }^{143}$ There is also a concern that judges will be doing a less thorough job in cases where they do not publish an opinion. Furthermore, when a court issues a ruling without endorsing the principles leading to that ruling, it may raise the suspicion that the decision is not a principled one, but rather, is motivated by a fact-driven desire to reach a particular outcome in the case immediately before it.

\section{Judicial Voting}

A fourth key aspect of the constitution for judicial lawmaking is the law governing judicial voting. Just as Article I of the United States Constitution sets forth the voting requirements to enact legislation, there are rules that define whether a particular judicial decision has the requisite votes to become an effective act of judicial lawmaking. As in most legislatures, judicial lawmaking requires a majority of all voting judges. While a judge who disagrees with the majority may write an opinion (either a dissent or concurrence), that separate opinion does not create binding law. When an appellate panel splits two to one, an en banc court splits nine to eight, or the Supreme Court splits five to four, the majority opinion- not the dissent-is

141. E.g., Boyce F. Martin, Jr., In Defense of Unpublished Opinions, 60 Оніо Sт. L.J. 177 (1999); Philip Nichols, Jr., Selective Publication of Opinions: One Judge's View, 35 Am. U. L. Rev. 909 (1986).

142. E.g., Cappalli, supra note 37, at 781-93; Martha J. Dragich, Will the Federal Courts of Appeals Perish if They Publish? Or Does the Declining Use of Opinions to Explain and Justify Judicial Decisions Pose a Greater Threat?, 44 Am. U. L. Rev. 757, 801 (1995); Johanna S. Schiavoni, Who's Afraid of Precedent?: The Debate over the Precedential Value of Unpublished Opinions, 49 UCLA L. REv. 1859 (2002); Jon A. Strongman, Unpublished Opinions, Precedent, and the Fifth Amendment: Why Denying Unpublished Opinions Precedential Value is Unconstitutional, 50 U. KAN. L. REv. 195, 196 (2001).

143. It is also questionable whether judges are accurately distinguishing cases that will and will not create precedent. See Cappalli, supra note 37, at 797 ("The courts have set up a Catch-22 system that seeks to spot precedentially valueless appeals as early as possible in order to conserve energy while failing to invest the time and effort essential to making that judgment accurately."). 
an effective act of judicial lawmaking, even though the difference may be only a single vote.

But this intuitively obvious principle is more difficult to apply when the judges and justices vote in more complex combinations. Even where all of the judges or justices agree on the outcome of a case (e.g., affirmed or reversed), there may be substantial disagreement on the reasoning that leads to that outcome. Because the reasoning may be important to determining the lawmaking effect of a particular decision, ${ }^{144}$ such divisions can make it very complicated to determine what parts of the various judicial opinions are effective acts of judicial lawmaking.

Before addressing how voting rules apply in more complex permutations of judicial opinions, it is helpful to start with the basics. Obviously, when at least five out of nine justices fully concur in one majority opinion, that opinion creates binding precedent and, subject to the other constitutional requirements for judicial lawmaking, is an effective lawmaking act. The same result occurs when two out of three judges on a federal appellate panel concur in a majority opinion.

Suppose, however, that two justices do not participate in the decision of a particular case. If the court splits four to three, the four-justice opinion has a majority of the voting justices, but not a majority of all justices. ${ }^{145}$ In this situation, only a majority of the voting justices is required. ${ }^{146}$ This would be consistent with the voting requirements for legislative lawmaking. If the vote in the Senate is forty-nine in favor, forty-eight against, and three abstaining, that legislation passes even though forty-nine votes is not a majority of the all senators. It is sufficient because it is a majority of the voting senators.

For judicial lawmaking, the true complications arise when no opinion garners a majority of the voting judges or justices. An oft-cited example of this is Regents of University of California v. Bakke, ${ }^{147}$ which addressed the permissibility of a California program that reserved sixteen out of 100 seats

144. See supra Part III.A.

145. The same scenario could occur in an en banc sitting of a federal appellate court. It could not occur in a three-judge appellate panel, because a minimum of two judges must participate in such a panel. In that situation, both judges must agree in order to obtain a majority. The only other possible outcome-a 1-1 split —would not create a majority of the voting judges.

146. See, e.g., Hoover v. Ronwin, 466 U.S. 558 (1984) (deciding case 4-3 and noting that Justices Rehnquist and O'Connor took no part in the consideration of the case); Hybud Equip. Corp. v. City of Akron, 742 F.2d 949, 957 (6th Cir. 1984) (citing Hoover's holding and acknowledging that it was a 4-3 decision); Easterbrook, supra note 11, at 53 (citing Hoover's holding and acknowledging that it was a 4-3 decision).

147. Regents of the Univ. of Cal. v. Bakke, 438 U.S. 265 (1978). 
in a medical school class for members of certain minority groups. The case generated six separate opinions, and no opinion garnered a majority of the Court. Four justices would have invalidated the program on statutory grounds, without deciding the program's constitutionality. ${ }^{148}$ Four other justices would have found the program constitutional and permissible under the relevant statute, on the basis that the program's racial classifications were allowed if designed to remedy disadvantages created by past discrimination. ${ }^{149}$ Justice Powell, the tie-breaking fifth vote, reasoned that racial classifications were permissible if appropriately employed to achieve "a diverse student body." The California system, however, was unconstitutional because it set a "specified percentage of the student body" that would be "in effect guaranteed to be members of selected ethnic groups."

When the Court is as fractured as it was in Bakke, which aspects of the various decisions are effective acts of lawmaking? The prevailing rule in the federal system is the so-called "narrowest grounds" rule endorsed in Marks $v$. United States. ${ }^{152}$ In Marks, the Supreme Court explained:

When a fragmented Court decides a case and no single rationale explaining the result enjoys the assent of five Justices, the holding of the Court may be viewed as that position taken by those Members who concurred in the judgments on the narrowest grounds .... ${ }^{153}$

How, then, would the Marks rule apply to a case like Bakke? At first glance, it would appear that Justice Powell's opinion would be the "narrowest ground," as he recognized that race could permissibly be used to attain diversity, but narrowly held that the quota system employed in California was not an appropriate means to that end. That said, there was considerable disagreement in the federal appellate courts over whether Powell's decision constituted Bakke's holding. ${ }^{154}$ And in the recent case of Grutter v. Bollinger, ${ }^{155}$ when the Supreme Court revisited the constitutionality of affirmative action programs in higher education, the Court declined to decide

148. Id. at 408 (Stevens, J.).

149. Id. at 325 (Brennan, White, Marshall, and Blackmun, JJ.).

150. Id. at 311-12 (Powell, J.).

151. Id. at 315 .

152. Marks v. United States, 430 U.S. 188 (1977).

153. Id. at 193 (internal quotation marks and citations omitted).

154. See Grutter v. Bollinger, 123 S. Ct. at 2325, 2337 (2003) (citing conflicting cases in the federal courts of appeals).

155. 123 S. Ct. 2325 (2003). 
whether Justice Powell's opinion in Bakke was binding under the Marks test, noting that the Marks test "is more easily stated than applied." 156

It is not hard to imagine hypothetical permutations of opinions that make it even more difficult to discern which opinion is based on the "narrowest grounds." 157 Suppose that Roe v. Wade produced a three-way split in the Supreme Court. This time, three Justices supported the conclusion that a state may not ban abortions for the first two trimesters of pregnancy. Three Justices reasoned that a state may not ban abortions only during the first trimester of pregnancy. The remaining three reasoned that the state can always ban abortions, provided the mother has an opportunity to seek a judicial exception in the event of rape or issues relating to the mother's health or well-being. Because the Texas statute failed under all of these rules, the court unanimously struck it down.

In this hypothetical, what would be the Court's holding under the Marks test? Which is the narrowest holding that supports the Court's ultimate conclusion? It would be easy to say that the Justices who would preserve the right to choose only for the first trimester of pregnancy have decided on a narrower ground than the Justices who would preserve the right to choose for the first and second trimester. But what about the third opinion, which would allow an absolute ban provided that judicial exception procedures were in place? Is that a narrower ground or a broader ground? It is not surprising, then, that the Supreme Court and the federal appellate courts have at times expressed frustration with the Marks test. ${ }^{158}$

\section{Making Sense of the Constitution for Judicial Lawmaking}

Each of the areas discussed above raise important issues about the judiciary's lawmaking function. Dicta, stare decisis, unpublished opinions, and judicial voting have all spawned significant academic attention, yet there remains a great deal of uncertainty about what each of these fundamental rules of judicial lawmaking requires as a practical matter. It is well beyond the scope of this article to propose comprehensive solutions with respect to any one of these areas, much less all of them. Rather, my goal is to begin to

156. Id. at 2337 (quoting Nichols v. United States, 511 U.S. 738, 745 (1994)).

157. Marks, 430 U.S. at 193.

158. See Nichols, 511 U.S. at $745-46$ (questioning whether it would be "useful to pursue the Marks inquiry to the utmost logical possibility when it has so obviously baffled and divided the lower courts that have considered it"). 
examine these issues in the broader context of the implicit constitution that governs the judicial lawmaking process.

To put the current system in perspective, I will compare it to two hypothetical judicial lawmaking institutions. At one extreme would be a judicial system that has no prospective lawmaking authority. Under this system no aspect of a judicial decision makes law that binds future cases, so the court's result, rationale, and any rules that it articulates in the course of deciding a case perform no lawmaking function. Because this approach is similar to the conventional view of civil law systems, I will call this the "civil model." 159 At the other extreme would be a system where courts have authority analogous to legislative bodies. They are free to make law regardless of whether the law they make is related to a particular case before it, they may change the law for any reason (or no reason), and they are free not to make law if they so desire. I call this the "legislative model." The central question for making sense of our constitution for judicial lawmaking is this: What goals are served by our current system as compared to alternative judicial systems?

\section{A. Why Should Courts Make Law at All?}

An argument could certainly be made in favor of the civil law approach, under which courts would not have the power to make law prospectively. While courts are necessary to resolve particular disputes, to endow them with prospective lawmaking authority would allow unelected judges to usurp the role of democratically elected legislatures. Arguably, the civil law approach enhances the legitimacy of the overall system because it leaves lawmaking to democratically-elected institutions.

On closer analysis, however, the effect of judicial lawmaking authority on legitimacy is more complex. A system where courts are free to decide cases knowing that the decision will not bind them in the future could undermine the legitimacy of the court by permitting arbitrary or unprincipled decisionmaking. The essence of principled decisionmaking, arguably, is to base decisions on principles that will hold fast beyond just the immediate case. Thus, allowing broad judicial lawmaking can legitimate the judicial role, because it helps to ensure that decisions are reached in a principled manner. ${ }^{160}$

159. But cf. Mitchel de S.-O.-I'E. Lasser, Judicial (Self-)Portraits: Judicial Discourse in the French Legal System, 104 YALE L.J. 1325 (1995)(arguing thatjudicialdecisions by French courts create precedent analogous to common law jurisdictions).

160. See Dorf, supra note 104, at 2040 ("[A] commitment to the rule of law and a proper 
This explains why judicial decisions that overtly seek to limit their application beyond the instant case are often viewed skeptically. Such decisions raise the specter that the ruling is based not on a neutral articulation or application of governing principles, but rather on a bare desire to reach a particular outcome in the case before it. The per curiam opinion in Bush v. Gore is a good example of this. Uncomfortable with the possible future impact of the equal protection principles employed to reach the decision that the Florida recount was unconstitutional, the Court was quick to clarify that "[o]ur consideration is limited to the present circumstances." ${ }^{161}$ This has been a frequent basis for criticism of the Bush v. Gore opinion. ${ }^{162}$

Judicial lawmaking is also valuable to the extent that it can provide guidance for future courts or private parties where such guidance is lacking in the governing constitutional or legislative enactments. Those who draft statutes and constitutional provisions will not be able to anticipate every situation that might arise when such enactments are applied in practice. To the extent that judges can fill in gaps or provide more concrete definitions of broad statutory or constitutional concepts, judicial lawmaking allows legal norms to be applied more consistently and with greater notice to the parties governed by them.

\section{B. Why Place Limits on Judicial Lawmaking?}

Given the benefits that can result from endowing courts with prospective lawmaking authority, why not adopt the legislative model? Why not allow courts to act essentially as legislatures, filling in gaps and expounding on statutory and constitutional provisions whenever they perceive a need for such lawmaking activity? There are a number of reasons. First, requiring courts to decide issues in the context of particular cases allows them to do so with briefing, argument, and evidence from the parties to the dispute. All other things equal, judicial lawmaking will not be as well-informed if it is done without such input from the parties to the litigation.

Second, limits on judicial lawmaking can help ameliorate the countermajoritarian concerns surrounding lawmaking activity by unelected judges. While there are benefits to allowing judges to fill in gaps and

\footnotetext{
understanding of the source of legitimate authority in our constitutional order will result in a holding/dictum distinction that turns on rationales, not just facts and outcomes.").

161. Bush v. Gore, 531 U.S. 98, 109 (2000).

162. E.g., Samuel Issacharoff, Political Judgments, 68 U. ChI. L. Rev. 637, 650 (2001) (characterizing this language as a "disingenuous limiting instruction").
} 
articulate principles to guide the application of broad provisions, the unbounded ability to do so could enable judges to act a bit too much like legislatures. Suppose judges are free to make law and change that law whenever they see fit, regardless of whether such lawmaking relates to a particular case before it. Not only is such lawmaking virtually indistinguishable from what legislatures do, but such an approach could undermine many of the benefits judicial lawmaking provides. For example, if courts may change judicially-created law at their whim, the consistency and certainty that judicial lawmaking purports to create vanishes.

\section{Revisiting the Articles of Judicial Lawmaking's Constitution}

Thus the constitutional contours of judicial lawmaking can impact the quality of such lawmaking in a number of ways. First, it can increase the likelihood that judicial lawmaking acts are well-informed, by ensuring that the issues about which the court is making law are ones addressed in the argument and evidence presented by the parties. Second, it can enhance both the predictability and legitimacy of judicial decisionmaking by requiring the consistent application of judge-made law, absent a heightened showing that justifies a change to the governing legal principles.

Third, it can reduce the possibility for opportunistic behavior by courts. While legislatures have the freedom to make law proactively in any area within their enumerated powers, the constitutional contours of judicial lawmaking may render the judiciary a more passive lawmaking institution. If a court can make law only in the context of actual cases brought before them by parties to litigation, the judicial lawmaking agenda is set by litigants, not the judges themselves. ${ }^{163}$ These three qualitative dimensions can illuminate constitutionalist analysis of the rules governing judicial lawmaking generally, as well as the particular facets of judicial lawmaking discussed in this article.

163. How robust a constraint this is as a practical matter is open to debate. Compare H.W. PERRY, Jr., Deciding to Decide: Agenda Setting in the United States Supreme Court (1991) ("While it is true that a legitimate case or controversy must exist and be appealed, this requirement is not really much of a constraint if the Court does not want it to be. Virtually any issue the Court might wish to resolve is offered to it."), with Evan H. Caminker, Sincere and Strategic Voting Norms on Multimember Courts, 97 Мich. L. REv. 2297, 2357 \& n. 168 (stating that the Supreme Court "lacks affirmative agenda control" since the Court "cannot create a vehicle for deciding a particular issue; it must await one"). 


\section{Dicta and Holdings: Beyond the Outcome-Rationale Debate}

Whether a court's holding includes the rationale or merely the outcome may be helpful as a basic way to articulate competing visions of the holdingdicta distinction. Ultimately, however, this debate is of limited use. One must always look to the court's rationale, if only to determine what legal issue is being decided. Did the defendant win: (a) because there was no personal jurisdiction over the defendant; (b) because there was no consideration to establish a binding contract; or, (c) because any error committed in the trial court was harmless error? Was the habeas corpus petition denied: (a) because it was time-barred; (b) because the defendant could not establish that his attorney had performed below the required level of competence; or, (c) because the defendant could not establish a reasonable probability that the result would have been different had the attorney acted competently? In order to even understand the legal issue for which the court's decision could make law, we must necessarily look at the court's rationale.

At the very least, therefore, determining a court's holding requires some analysis beyond the mere outcome. So, the question, is not whether we look to the court's rationale, but which parts of that rationale constitute effective acts of judicial lawmaking. ${ }^{164}$ Accordingly, a more useful distinction may not be between outcomes and rationales, but between rationales and rules. Not all rationales are necessarily rules. To find that a certain requirement is met because of particular facts present in a given case is a rationale, but it does not, standing alone, state a rule. That the court finds certain facts to be dispositive in one case does not necessarily mean that those same facts will be dispositive in another case where other facts are present. It does make law insofar as it establishes a point on the spectrum of facts that satisfy a particular legal standard. In this sense, a decision makes law only as to the outcome of that case.

164. Some have expressed the view that the words contained in a judicial opinion can never be law. See Cappalli, supra note 37, at 774 ("Every word of a statute is law; no word of a judge is law."). While it is true that "the process of interpreting and applying a precedent is in the hands of the future user, and even the sharply reasoned and written opinion loses control to these users when it is issued," $i d$. at 775 , the same is true of a statute. See id. at 783 (noting that under "the new American common law ... words chosen by judges for their opinion have some controlling future force, just like a statute"). Both the statute and the judicial opinion, however, constitute effective acts of lawmaking, provided they comply with the constitutional requirements for such lawmaking. 
Suppose, however, that the court states a rule - for example, "race-based classifications are subject to strict scrutiny," 165 or "abuse-of-discretion" is the standard of review for "a trial court's decision to admit or exclude expert testimony." the judiciary is not legitimate, ${ }^{167}$ and others argue that it is unwise. ${ }^{168}$ But most agree, as a general principle, such rules can constitute part of the court's holding. ${ }^{169}$ A fundamental question from the standpoint of the constitution that governs judicial lawmaking is, when does the presence of a disconnect between the rule and the facts, or between the rule and the result, render the rule (or part of the rule) dicta?

As described above, there is a tension inherent in the dicta-holding distinction. On one hand, confining the court's holding narrowly arguably prevents courts from acting legislatively by making law beyond the facts of the case immediately before it. On the other hand, according binding effect to broader principles on which courts rely can help prevent arbitrary decisionmaking and legitimate the judicial role by requiring the same governing legal principles to apply to all litigants. These two effects are in direct conflict, and our system of judicial lawmaking cannot have one without the other. Finding the optimal balance is the critical issue for determining the precise line between ineffective dictum and a binding effective holding.

Where can the balance be struck? The paradigmatic example of dicta, of course, is where the court says, "Rule A applies to cases in category X, and it also applies to category Y." Or, conversely, "Rule A applies to cases in category X, but it would not apply to category Y." If the case before the court involves only category $\mathrm{X}$, then to opine on what rule would govern category $\mathrm{Y}$ is classic dicta. Suppose a court states the rule " $[\mathrm{u}]$ nder the equal protection clause, strict scrutiny applies to legislative distinctions based on race and gender." If the case before it involves a racial classification, then it would be dicta to state the level of scrutiny required for gender issues. Although the stated rule is logically connected to the court's outcome, the content of the

165. See Grutter v. Bollinger, 123 S. Ct. 2325, 2338 (2003) ("We apply strict scrutiny to all racial classifications.").

166. See Kumho Tire Co. v. Carmichael, 526 U.S. 137, 152 (1999) (“[A] court of appeals is to apply an abuse-of-discretion standard when it reviews a trial court's decision to admit or exclude expert testimony.") (citation and internal quotation omitted).

167. Peters, supra note 4, at 410 (noting the "inherent illegitimacy" of applying "judicially promulgated rules").

168. SunsteIn, supra note 80, at 121.

169. E.g., Alexander, supra note 105, at 48-53. 
rule improperly exceeds the facts before it by stating a rule that applies to gender as well.

Stating the level of scrutiny for gender classifications in a race case seems like classic dicta. However, accepting this non-controversial proposition can devolve into a pure result-based approach if taken to extreme. This is because the relevant categories can be defined at various levels of specificity. If category $\mathrm{X}$ is defined as narrowly as possible, i.e., the precise facts of the case before it, then applying the stated rule to any other case would necessarily implicate some category $\mathrm{Y}$ and, therefore, constitute dicta. Roe v. Wade provides a good example. Chief Justice Rehnquist would define category $\mathrm{X}$ as those statutes that criminalize all abortions unless the life of the mother is at stake. ${ }^{170}$ Thus, according to Rehnquist, statutes that impose different restrictions fall into category $Y$, and any statement by the court that purports to apply to those other statutes is dicta.

One solution, it seems, is to determine whether the stated rule can be limited in a way that does not affect the logical coherence of the court's reasoning. The holding of Roe $v$. Wade does not need to be limited as Chief Justice Rehnquist would require, because the logic of Roe-which seeks to balance the mother's fundamental rights with the government's interest in the mother's safety and the protection of a fetus after viability - applies with equal force to regulations other than the restrictive Texas statute challenged in Roe. An equal protection challenge to racial classifications, on the other hand, does not logically need to address the scrutiny applied to gender classifications.

Another illustrative example is last term's Supreme Court decision in Lawrence v. Texas, ${ }^{171}$ which struck down the Texas statute criminalizing homosexual sodomy and overruled Bowers v. Hardwick. ${ }^{172}$ The Court could have decided Lawrence solely on equal protection grounds, on the basis that the statute criminalized homosexual sodomy but not heterosexual sodomy. ${ }^{173}$ But the logic of the Court's opinion — based on an individual's substantive due process rights - applied equally to both heterosexual and homosexual sodomy. ${ }^{174}$ The articulation of this requirement is an effective act of

170. Webster v. Reprod. Health Servs., 492 U.S. 490, 501 n.1, 520-21 (1989).

171. Lawrence v. Texas, 123 S. Ct. 2472 (2003).

172. Bowers v. Hardwick, 478 U.S. 186 (1986).

173. Lawrence, $123 \mathrm{~S}$. Ct. at 2484 ("Rather than relying on the substantive component of the Fourteenth Amendment's Due Process Clause, as the Court does, I base my conclusion on the Fourteenth Amendment's Equal Protection Clause.") (O'Connor, J., concurring) (emphasis original).

174. Id. at 2483-84. 
lawmaking, even though it was theoretically possible to decide the case on narrower grounds.

How would this approach affect the considerations discussed above? As long as the parties to the case raise the issues addressed by the court, it is the parties — not the court — that sets the agenda. So, when Mr. Lawrence argues substantive due process as well as equal protection, it is appropriate for the court to address both issues. The rule that a court's alternative holdings each have binding legal effect presumes that a court may address more than one issue. Likewise, where the parties present evidence and argument on broader and narrower issues, the decision by the court will be equally well-informed for both. And with respect to both issues, the court can provide important guidance that can provide consistency, certainty, and notice to future litigants. Finally, if judicial lawmaking's legitimacy stems in part from an expectation of principled decisionmaking, then according lawmaking effect to the logical extent of the underlying principles would not undermine that legitimacy.

What about the situation where the court's resolution of a preliminary issue, such as a standard of review, is rendered unnecessary by the court's application of that standard. Recall, again, the facts of Washington $v$. Schriver. ${ }^{175}$ The case presented two issues: (1) the proper standard of review in habeas corpus actions that challenge particular state court rulings, and (2) whether the petitioner was entitled to relief under the governing standard. Judge Calabresi concluded that it would be dicta to decide that a particular issue was governed by a de novo, rather than a deferential, standard of review, if the decision being reviewed passed muster even under the more rigorous standard. ${ }^{176}$

But is there any reason to prevent the court from deciding the appropriate standard of review simply because of the outcome reached when applying that standard? It is the parties, after all, who place the standard of review on the court's agenda. Admittedly, the court's ultimate application of the standard of review makes it such that the court could have avoided the question-by assuming the more rigorous standard of review and holding that the state court's decision would pass muster anyway. It does not follow, however, that a court that addresses the standard of review issue does so only in dicta. The

175. 240 F.3d 101 (2d Cir. 2001), superseded by 255 F.3d 45 (2d Cir. 2001).

176. Washington, 255 F.3d at 64 ("'G]iven the unanimous agreement of the panel that the petitioner's claim fails even under non-deferential, pre-AEDPA review, any statement - as to which rule applies when State courts make no reference to the federal grounds for their decision-would in this case be dicta.") (Calabresi, J., concurring). 
decision on standard of review can provide important guidance to future litigants, and it does not come at the expense of judicial opportunism.

\section{Should Stare Decisis Be Part of Our Constitution for Judicial Lawmaking?}

As discussed above, stare decisis is not a constitutional limit on judicial lawmaking in most federal courts, including the United States Supreme Court. Stare decisis is, of course, an important and often dispositive principle even in the Supreme Court. ${ }^{177}$ But for purposes of articulating the implicit constitution for judicial lawmaking, the critical question is whether a court's failure to follow stare decisis renders a particular decision an ineffective act of lawmaking. Certainly, stare decisis implicates the principles discussed above in several ways. To allow courts to change the law without making the heightened showing required to justify such a change will substantially undermine the guidance, consistency, and certainty that judicial lawmaking helps to foster. The benefits that judicial lawmaking creates would be lost if future courts were free to modify that law without sufficient justification. In addition, stare decisis impacts the legitimacy of judicial decisionmaking. If courts may disregard the principles articulated in prior cases without proper justification, the legitimating notion that cases are reached in a principled manner is eroded. ${ }^{178}$

That said, the hierarchy of the federal court judiciary may allow for some intermediate solutions. For example, one might propose that stare decisis should be a constitutional limit on lower federal courts but not on the Supreme Court. Since most cases are resolved in the lower federal courts without any Supreme Court review, ${ }^{179}$ giving stare decisis constitutional teeth in the lower courts would create meaningful consistency for the vast majority of litigants. For the Supreme Court, however, one could argue that stare decisis should not be a constitutional requirement. Because the Supreme Court decisions make law for the entire nation, it arguably should be free to make law as best it can

177. See Casey, 505 U.S. at 853 ("[T] he reservations any of us may have in reaffirming the central holding of Roe are outweighed by the explication of individual liberty we have given combined with the force of stare decisis.").

178. See supra, Part IV.A.

179. See Henry J. Bemporad \& Sarah P. Kelly, Novel Issues, Futile Issues, and Appellate Advocacy: The Troubling Lessons of Bousley v. United States, 35 ST. MARY's L.J. 93, 109 n.89 (2003) (“The U.S. Supreme Court grants review of only 100 cases each year of the more than 7000 petitions it receives.") (citing The Justices' Caseload, A BriefOverview of the Supreme Court, at http://www.supremec ourtus.gov/ about/justicecaseload.pdf) (last visited Jan. 17, 2004). 
without being constitutionally constrained by prior decisions that may have been wrongly decided. And since the Supreme Court addresses particular issues much less frequently than the lower federal courts, the costs in terms of inconsistency are, arguably, comparatively less.

Again, the following point is critical. Whether stare decisis is or should be a constitutional requirement (as I define that term) is a separate question from whether it should be applied in some or even all cases. From a constitutional perspective, the question is whether a lawmaking act that does not follow stare decisis may be treated as ineffective, i.e., whether stare decisis should render a more recent decision invalid on the basis that it conflicts with an earlier one. ${ }^{180}$ Just as people who support a particular policy choice can disagree as to whether that policy choice is constitutionally mandated, people who support stare decisis can also differ over whether that principle is a constitutional limit on judicial lawmaking.

\section{Unpublished Decisions and the Power Not to Make Law}

Under the current federal system, the constitution for judicial lawmaking authorizes courts to issue unpublished decisions and, thereby, deprive the decision of any lawmaking effect. ${ }^{181}$ What do the principles underlying the constitution for judicial lawmaking have to say about this issue?

As discussed above, critics of unpublished decisions fear that rulings may be unprincipled if judges make them knowing that the unpublished opinion will not bind them in future cases. Thus, the practice of unpublished decisions may impact the legitimacy of judicial decisionmaking, as described above. Likewise, from the standpoint of consistency and guidance, unpublished opinions allow for inconsistency in decisionmaking that might be avoided if the earlier opinions were published and, therefore, legally binding. On the other hand, it could be argued that allowing unpublished decisions can improve the overall consistency of judicial lawmaking, because judges can concentrate their efforts on analyzing and synthesizing the published cases, with an eye toward maintaining a coherent and consistent body of law. ${ }^{182}$

180. In this sense, treating stare decisis as a constitutional requirement would have counterintuitive consequences. The conventional wisdom is that courts and practitioners find recent authority more persuasive than older authority. To treat stare decisis as a constitutional limit on judicial lawmaking, however, would by necessity elevate the status of older case law.

181. See supra Part III.C.

182. E.g., Martin, supra note 141, at 177; Nichols, supra note 141, at 909. 
The practice of unpublished decisions also has mixed consequences in terms of judicial opportunism. In one sense, allowing unpublished decisions minimizes such opportunism, because it permits courts to refrain from making law even where they are otherwise authorized to do so in light of the issues presented in a given case. On closer analysis, however, the authority to deprive decisions of lawmaking effect can enable judges to manipulate the agenda-setting process. A judge may use an unpublished decision to put off deciding a particular issue until a case comes along that is better-suited to his or her particular views. ${ }^{183}$

But what, exactly, is the alternative? Suppose judges were deprived of the ability to make unpublished decisions. Given the judiciary's general support for the practice, ${ }^{184}$ there is a possibility that judges who would otherwise write unpublished opinions may simply issue summary decisions (e.g. "Affirmed") with no opinions at all.

There may, however, be a middle ground. Presently, the rules on unpublished decisions adopted by the federal courts of appeals fall into two categories: rules providing that unpublished decisions are not binding precedent and rules prohibiting parties from citing to unpublished decisions, even as persuasive (though not binding) authority. ${ }^{185}$ Assume an unpublished decision contains language that, if published, would make law X. If the court simply treats that decision as non-binding precedent, then it has put off for another day whether X should be the law. But even if one accepts the court's authority to put off that decision, it does not follow that future parties should be barred from citing that unpublished decision in support of arguing that $\mathrm{X}$

183. In this way, unpublished decisions in the lower federal courts are similar to denials of certiorari by the Supreme Court. Like an unpublished decision, the Supreme Court's denial of certiorari is not an act of lawmaking. See Maryland v. Baltimore Radio Show, 338 U.S. 912, 917 (1950) (opinion of Frankfurter, J.). But, such denials conceivably allow the Supreme Court to manipulate the agenda and, thereby, allow justices inclined to make law in a particular way to wait for a case that presents a factual scenario best suited to the legal precedent they would like to set. $C f$. Edward A. Hartnett, Questioning Certiorari: Some Reflections Seventy-Five Years After the Judges' Bill, 100 Colum. L. Rev. 1643, 1718 (2000) ('[The certiorari power] gave the Supreme Court an important tool with which to exercise will. The ability to set one's own agenda is at the heart of exercising will."). masse").

184. See Cappalli, supra note 37, at 760 (noting "that judges support the non-precedent policy en

185. Compare 10TH CiR. R. 36.3(B) ("[A]n unpublished opinion may be cited if: (1) it has persuasive value with respect to a material issue that has not been addressed in a published opinion; and (2) it would assist the court in its disposition.") with 9TH CIR. R. 36-3(b)

Unpublished dispositions and orders of this Court may not be cited to or by the courts of this circuit, except ... when relevant under the doctrine of law of the case, res judicata, or collateral estoppel ... [or] for factual purposes, such as to show double jeopardy, sanctionable conduct, notice, entitlement to attorneys' fees, or the existence of a related case. 
should be adopted as the law. That a prior decision is not binding does not necessarily mean it should not be cited. After all, parties litigating in one circuit frequently cite cases from other circuits or from state courts, even though authority from those other jurisdictions are not binding. Litigants even cite law review articles and foreign law, despite the fact that they are not formally binding on any United States tribunal.

It is somewhat perverse that a litigant in the Ninth Circuit may cite law from the Eighth Circuit, the Western District of Tennessee, and the Supreme Court of Vanuatu, but may not cite a case rendered by the very judges on the Ninth Circuit. Charting the middle course, under which courts may continue to deny unpublished decisions precedential value but could not preclude their citation for persuasive value, is one way to balance various practical realities surrounding this issue. ${ }^{186}$

\section{Judicial Voting and One Alternative to Marks-ism}

Judicial voting rules raise intriguing questions from the standpoint of the constitution that governs judicial lawmaking. When a fractured court fails to produce a majority opinion, one alternative is to treat the court as a legislature. If an opinion does not garner a majority, it does not make law. This would seem to minimize judicial opportunism, since only a true majority of voting judges would be authorized to make law. This approach would not, however, seem to advance the goals of consistency and clarity, as the law would remain unsettled.

The narrowest grounds rule of Marks, perhaps, is an awkward attempt to balance these concerns. Even where no opinion garners an absolute majority, the Marks approach permits the court make law and, thereby, clarify the area of the law at issue. And perhaps allowing the narrowest ground to prevail roughly approximates majoritarian decisionmaking. Take Bakke, for example. Justice Powell — whose concurrence is arguably the holding under the Marks

186. See, e.g., Stephen R. Barnett, From Anastasoff to Hart to West's Federal Appendix: The Ground Shifts Under No-Citation Rules, 4 J. ApP. PrAC. \& Process 1 (2002); Charles E. Carpenter, Jr., The No-Citation Rule for Unpublished Opinions: Do the Ends of Expediency for Overloaded Appellate Courts Justify the Means of Secrecy?, 50 S.C. L. Rev. 235 (1998); Kirt Shuldberg, Digital Influence: Technologyand Unpublished Opinionsin the Federal Courts of Appeals, 85 CAL. L. REv. 541, 574 (1997). One commentator has argued that "no citation" rules, such as the Ninth Circuit's, constitute an impermissible prior restraint in violation of the First Amendment. Marla Brooke Tusk, No-Citation Rules as a Prior Restraint on Attorney Speech, 103 Colum. L. Rev. 1202, 1226-30 (2003). 
test-is essentially the "median voter." Basic voting theory posits that majoritarian processes will reflect the preference of this median voter. ${ }^{187}$

The problem is that the "narrowest ground" is not always ascertainable. One alternative to Marks that may address this problem approach is what I call the matrix theory. In linear algebra, a matrix is a set of functions to be performed on a particular set of numbers. Rather than a single function, the matrix provides a simple way to depict multiple functions. The Marks rule seeks to identify a single function - the "narrowest grounds" among the relevant opinions - to be the court's holding in a particular case. The matrix theory, on the other hand, would treat each decision-regardless of whether it supports or opposes the majority disposition - as a separate function, each to be applied to the facts of subsequent cases. Each opinion would be accorded the weight of the number of judges who support the decision.

In a case like Bakke, the matrix approach would probably yield a result similar to Marks. When applied to a particular affirmative action program, one would apply the opinion of Justice Stevens (joined by Chief Justice Berger, Justice Stewart, and Justice Rehnquist) and assign four votes to that. One would apply the holding of Justices Brennan, White, Marshall, and Blackmun and assign four votes to that. Finally, one would apply Justice Powell's opinion and assign one vote to that. In most cases, Justice Powell's opinion will be the median voter and, therefore, will be the tie-breaking vote under the Bakke matrix. But the matrix approach reaches this result without addressing the often murky question of which opinion is technically the "narrowest."

The matrix theory will also provide a means for dealing with cases like the hypothetical abortion decision described above. To summarize, this hypothetical yielded the following opinions, each of which received three votes in support:

Opinion 1: A state may not ban abortions for the first two trimesters of pregnancy.

Opinion 2: A state may not ban abortions during the first trimester of pregnancy.

Opinion 3: A state can always ban abortions, provided the mother has an opportunity to seek a judicial exception.

A statute that bans abortions only in the third trimester of pregnancy would be permissible, because it would be constitutional under both Opinion

187. E.g., Curtis J. Milhaupt, Nonprofit Organizations as Investor Protection: Economic Theory and Evidence from East Asia, 29 YALE J. INT'L L. 169, 181 (2004) (“'[I]n a democracy, . . decisions about which public goods to produce and in what quantity will most often reflect the preferences of the median voter."). 
1 and Opinion 2. The fact that it did not provide any sort of judicial exception procedure in the third trimester is not required, because Opinions 1 and 2 are enough to obtain the necessary six votes. A statute that bans abortions in the second and third trimester but provides for a judicial exception procedure would also be constitutional, because Opinions 2 and 3 would uphold them. The fact that it does not allow the right to choose in the second trimester would not be a problem, because Opinions 2 and 3 already garner the required votes. On the other hand, a statute that banned abortions in the second and third trimester and provided no judicial exception procedure would fail to pass muster. While Opinion 2 would uphold that statute, it would fail under Opinions 1 and 3 and, therefore, would be struck down six to three.

This approach, admittedly, is somewhat cumbersome. But at the same time, it is not uncommon for lower courts, attempting to make sense of complicated areas of Supreme Court case law, to require that multiple tests be applied when deciding a particular issue. The Supreme Court's Establishment Clause jurisprudence is an instructive example. Over time, the Supreme Court has articulated a variety of tests to determine whether a governmental act related to religion is constitutional under the Establishment Clause. In Lemon v. Kurtzman, ${ }^{188}$ the Court held that a state practice is unconstitutional if it lacks a secular purpose, if its primary effect either advances or inhibits religion, or if it excessively entangles government with religion. ${ }^{189}$ In County of Allegheny v. ACLU, ${ }^{190}$ the Court stated the "endorsement" test, which analyzes whether state action endorses religion by conveying "a message that religion or a particular religious belief is favored or preferred." "191 Finally, under the coercion test set out in Lee $v$. Weisman, ${ }^{192}$ courts must examine whether a particular government act has the potential to make an objector feel obliged to participate in a religious activity. ${ }^{193}$ Attempting to make sense of these various tests, the federal appellate courts often require courts deciding Establishment Clause questions to apply all three of these tests. ${ }^{194}$

188. Lemon v. Kurtzman, 403 U.S. 602 (1971).

189. Id. at 612-13.

190. County of Allegheny v. ACLU, 492 U.S. 573 (1989).

191. Id. at 593-94.

192. Lee v. Weisman, 505 U.S. 577 (1992).

193. $I d$.

194. E.g., Freiler v. Tangipahoa Parish Bd. of Educ., 185 F.3d 337, 343 (5th Cir. 1999) ("In the context of public education, we have evaluated state action challenged on Establishment Clause grounds under each of three complementary (and occasionally overlapping) tests established by the Supreme Court.") (citation and internal quotation marks omitted). 
The appellate courts' treatment of Establishment Clause cases indicates that courts frequently apply multiple tests in the course of adjudicating a particular claim. So too could lower courts consider each opinion issued by a fractured court. While one might argue that the matrix theory's complicated approach does little to further the goals of clarity or consistency, its complexity is not fundamentally different from multi-part tests that $d o$ gain a majority of voting judges. At the end of the day, the key question raised by this approach is whether having a rule-of-decision that is cumbersome to apply is better than having no rule at all.

\section{CONCLUSION}

Proposing comprehensive solutions to every aspect of the constitution that governs judicial lawmaking is far beyond the scope of any single article. Nonetheless, the concept of a constitution for judicial lawmaking, analogous to constitutions that govern legislative lawmaking, is an important one. It adds a new theoretical dimension to scholarly debates about jurisprudential issues and questions of judicial authority. While scholars, practitioners, and judges often debate how courts should perform their lawmaking functions, they have yet to acknowledge the distinction between principles that create enforceable constitutional limits on judicial lawmaking and those that are left to the lawmaking courts themselves to apply.

For legislative lawmaking, this distinction is well-established. Legislative enactments may be analyzed on public policy grounds-e.g., the legislature was wise to enact this law, or the legislature should have enacted a different law. Or they may be analyzed on constitutional grounds-e.g., this law was a valid act of legislative lawmaking (regardless of its merits), or this law was invalid under the constitution that governs such lawmaking (regardless of its merits). A constitutional perspective on judicial lawmaking embraces the fact that judicial lawmaking may also be examined on these two distinct levels. Even where the constitution that governs judicial lawmaking is not embodied in a separate, written document, we can still identify those principles that are, as a functional matter, constitutional. Taking a constitutional approach to judicial lawmaking will thus allow judges, scholars, and practitioners to frame arguments about the judicial lawmaking function more sharply. Moreover, the principles underlying the constitution for judicial lawmaking can inform how these constitutional rules should operate. In the long run, this will lead to a more complete understanding of, and more focused debate about, judicial lawmaking in a variety of different contexts. 